\title{
Things Are Getting Hairy: Enterobacteria Bacteriophage vB_PcaM_CBB
}

\begin{abstract}
Colin Buttimer ${ }^{1}$, Hanne Hendrix ${ }^{2}$, Hugo Oliveira ${ }^{3}$, Aidan Casey ${ }^{4}$, Horst Neve ${ }^{5}$, Olivia McAuliffe ${ }^{4}$, R. Paul Ross ${ }^{4}$, Colin Hill ${ }^{6}$, Jean-Paul Noben ${ }^{7}$, Jim O'Mahony ${ }^{1}$, Rob Lavigne ${ }^{2}$ and Aidan Coffey ${ }^{1 *}$
\end{abstract}

\begin{abstract}
${ }^{1}$ Department of Biological Sciences, Cork Institute of Technology, Cork, Ireland, ${ }^{2}$ Laboratory of Gene Technology, KU Leuven, Leuven, Belgium, ${ }^{3}$ Laboratório de Investigação em Biofilmes Rosário Oliveira, Centre of Biological Engineering, University of Minho, Braga, Portugal, ${ }^{4}$ Teagasc Food Research Centre, Moorepark Fermoy, Co., Cork, Ireland, ${ }^{5}$ Department of Microbiology and Biotechnology, Max Rubner-Institut, Kiel, Germany, ${ }^{6}$ APC Microbiome Institute and School of Microbiology, University College, Cork, Ireland, ${ }^{7}$ Biomedical Research Institute and Transnational University Limburg, Hasselt University, Diepenbeek, Belgium
\end{abstract}

\section{OPEN ACCESS}

Edited by:

William Michael McShan, University of Oklahoma Health

Sciences Center, USA

Reviewed by:

Louis-Charles Fortier

Université de Sherbrooke, Canada Darren Lee Smith,

Northumbria University, UK Scott Van Nguyen,

United States Department of Agriculture, USA

${ }^{*}$ Correspondence: Aidan Coffey aidan.coffey@cit.ie

Specialty section

This article was submitted to Virology,

a section of the journal

Frontiers in Microbiology

Received: 15 November 2016 Accepted: 06 January 2017 Published: 24 January 2017

Citation:

Buttimer $\mathrm{C}$, Hendrix $\mathrm{H}$, Oliveira $\mathrm{H}$ Casey A, Neve H, McAuliffe $O$, Ross RP, Hill C, Noben J-P, O'Mahony J, Lavigne R and Coffey A (2017) Things Are Getting Hairy: Enterobacteria Bacteriophage VB_PcaM_CBB.

Front. Microbiol. 8:44 doi: 10.3389/fmicb.2017.00044
Enterobacteria phage vB_PcaM_CBB is a "jumbo" phage belonging to the family Myoviridae. It possesses highly atypical whisker-like structures along the length of its contractile tail. It has a broad host range with the capability of infecting species of the genera Erwinia, Pectobacterium, and Cronobacter. With a genome of 355,922 bp, excluding a predicted terminal repeat of $22,456 \mathrm{bp}$, phage CBB is the third largest phage sequenced to date. Its genome was predicted to encode 554 ORFs with 33 tRNAs. Based on prediction and proteome analysis of the virions, 29\% of its predicted ORFs could be functionally assigned. Protein comparison shows that CBB shares between $33-38 \%$ of its proteins with Cronobacter phage GAP32, coliphages PBECO4 and $121 \mathrm{Q}$ as well as Klebsiella phage vB_KleM_Rak2. This work presents a detailed and comparative analysis of vB_PcaM_CBB of a highly atypical jumbo myoviridae phage, contributing to a better understanding of phage diversity and biology.

Keywords: bacteriophages, genome, bioinformatics, mass spectrometry, Jumbo bacteriophage, PFGE analysis, host range, transmission electron microscopy

\section{INTRODUCTION}

Bacteriophages (phages) the viruses of bacteria are the most abundant biological entities in the biosphere with an estimated number of $10^{31}$ (Whitman et al., 1998; Hendrix, 2002). The order Caudovirales (the tailed phages) make up the greatest majority of the phages types that have been studied and within this order are the phage families of Myoviridae, Siphovirdae, and Podoviridae (Ackermann, 2001). Myoviridae have the most sophisticated virion design, possessing a tail capable of contracting on infection and generally having the largest genomes when compared to the other families (Hatfull, 2008). However, only a small number of the known Myoviridae phages have genomes greater than $200 \mathrm{kbp}$; and these are often referred to as "giant" or "jumbo" phages (Hendrix, 2009). The largest of these isolated to date are Bacillus megaterium phage G (498 kbp, accession no. JN638751.1), Cronobacter phage GAP32 (358 kbp, accession no. NC_019401), Escherichia phage PBECO4 (348 kbp, accession no. NC_027364) and Klebsiella phage Rak2 (345 kbp, accession no. NC_019526). The former three phages, GAP32, PBECO4, and Rak2 are recent 
discoveries, and their genomes have only been presented within the last 3 years (Kim et al., 2013; Šimolūnas et al., 2013; Abbasifar et al., 2014). These phages share a number of protein homologs with the T4-like phages, but they lack a number of universal core proteins found among the Myoviridae subfamily of Tevenvirinae. Due to the lack of sequence identity, the lack of an even distribution of homologs among their genomes with the T4-like phages and the possession of their own species-specific proteins, it has been proposed that these phages should be placed within a new subfamily (Abbasifar et al., 2014). More recently, there have been two additional phages that share homology to this subfamily (termed the Rak2-like phages from here onwards in this article) these are Escherichia phage 121Q (348 kbp, accession no. NC_025447.1) and Klebsiella phage K61-1 (346 kbp, accession no. AB897757).

This article presents morphological, genomic and structural proteomic findings on another newly isolated Rak2-like phage, Enterobacteria phage vB_PcaM_CBB. This is a broad host range jumbo phage which possesses highly atypical whisker-like structures along its contractile tail surface, a feature which has not been described in any of the other Rak2-like phages published to date.

\section{METHODS}

\section{Bacterial Strains, Phage, and Cultivation Conditions}

Phage $\mathrm{CBB}$ was isolated and propagated on Pectobacterium carotovorum subsp carotovorum strain CBBL19-1-37. Bacterial strains used for the host range study are listed in Supplementary S1, Table S1. Crystal Violet Pectate selective agar (Hélias et al., 2012) was used to isolate Pectobacterium strains from potatoes presenting symptoms of blackleg which were obtained from farms in Co. Cork, Ireland. Bacterial identification was achieved using biochemical tests as well as genus- and species-specific PCRs (Darrasse et al., 1994; De Boer and Ward, 1995; Kang et al., 2003). To grow bacterial stains and propagate the phage, Lysogeny broth (LB), LB agar (1.5\% w/v agar), and LB overlays $(0.2 \mathrm{w} / \mathrm{v}$ agarose) were used (Sigma- Aldrich, St. Louis, Missouri, United States). Incubation temperatures of $25^{\circ} \mathrm{C}$ were used for all cultures used in this study.

\section{Phage Techniques}

Phage enrichment and isolation was conducted as described by Van Twest and Kropinski (2009). The phage double overlay assay was conducted using overlays containing $0.2 \%$ agarose for morphologically large phage as described by Serwer et al. (2007). Stocks of phage were produced according to the plate lysis method described by Sambrook and Russell (2001a). To determine phage titre, a 10-fold dilution series of phage stock was tested with agarose overlay as described previously Sambrook and Russell (2001b). Host range assays of phage $\mathrm{CBB}$ were performed by spot assay as described by Mazzocco et al. (2009). Isopycnic centrifugation though $\mathrm{CsCl}$ gradients was performed as described by Sambrook and Russell (2001c) with a number of modifications. A high titre phage lysate $\left(>1 \times 10^{9}\right.$ plaque forming units $\left.(\mathrm{PFU}) / \mathrm{mL}\right)$, was precipitated using polyethylene glycol (15\% w/v PEG8000, $1 \mathrm{M} \mathrm{NaCl}$ ) at $4{ }^{\circ} \mathrm{C}$ overnight and centrifuged, after which the pellet was resuspended in TMN buffer $(10 \mathrm{mM}$ Tris$\mathrm{HCl}$ pH7.4, $10 \mathrm{mM} \mathrm{MgSO}_{4} .7 \mathrm{H}_{2} \mathrm{O}, 0.5 \mathrm{M} \mathrm{NaCl}$ ) followed by a chloroform phase separation step (1:1) to remove debris. The resulting phage preparation was placed onto a $\mathrm{CsCl}$ step gradient composed of $1.3,1.5$, and $1.7 \mathrm{~g} / \mathrm{ml}$ layers and spun in a $100 \mathrm{Ti}$ rotor (Beckman Coulter) at 200,480 $\mathrm{g}$ for $3 \mathrm{~h}$ at $4^{\circ} \mathrm{C}$. Resulting phage bands were collected and subjected to dialysis with two changes of Tris- $\mathrm{HCl}$ buffer $(10 \mathrm{mM}, \mathrm{pH} 7.5)$ at $4^{\circ} \mathrm{C}$.

\section{Transmission Electron Microscopy}

Phages were negatively stained on freshly prepared carbon films with $2 \%(\mathrm{w} / \mathrm{v})$ uranyl acetate. Micrographs were taken using a Tecnai 10 transmission electron microscope (FEI Thermo Fisher, Eindhoven, the Netherlands) at an acceleration voltage of $80 \mathrm{kV}$ with a MegaView G2 CCD-camera (emsis, Muenster, Germany).

\section{DNA Isolation and Sequencing}

DNA extraction was performed as previously described (Pickard, 2009). CsCl purified phage particles were treated with DNase and RNase, followed by treatment with $10 \%$ SDS and proteinase $\mathrm{K}$ followed by DNA extraction with phenol:chloroform:isoamyl alcohol (25:24:1 v/v) and chloroform: isoamyl alcohol (24:1 $\mathrm{v} / \mathrm{v})$. DNA quality and quantity were estimated using both a nanodrop (NanoDrop, ND-1000) and by visualization after agarose gel electrophoresis. Phage DNA was sequenced with a high throughput Illumina MiSeq System outsourced at Nucleomics Core (VIB, Belgium). Libraries were processed with a custom NEBNext ${ }^{\circledR}$ Ultra $^{\mathrm{TM}}$ DNA Kit to generate 500-bp fragments with individual barcodes. The quality of each library preparation was controlled using an Agilent Bioanalyzer and Qubit measurements, before being pooled together with a nonhomologous genome and sequenced with $2 \times 150$ bp pairedend reads. Demultiplex, quality controlled (above Q30) and trimmed reads were de novo assembled using CLC Bio Genomics Workbench v7.0 (Aarhus, Denmark) into a single contig. Contigs were resolved with $1,044,532$ reads and with an average coverage of $401 x$ for phage CBB.

\section{Pulsed Field Gel Electrophoresis}

Pulsed field gel electrophoresis (PFGE) was conducted as described by Lingohr et al. (2009). A CsCl purified phage suspension was mixed with an equal volume of low-melting point agarose (Bio-Rad Laboratories, Hercules, USA). Prepared plugs were placed in lysis buffer (50 mM Tris, $50 \mathrm{mM}$ EDTA, 1\% SDS) and digested with proteinase $\mathrm{K}$ for $2 \mathrm{~h}$ at $54^{\circ} \mathrm{C}$. Plugs were then washed twice with TE buffer (10 mM Tris, $1 \mathrm{mM}$ EDTA [pH8.0]) and subjected to electrophoresis on a $1 \%$ agarose gel using Bio-Rad CHEF-DR ${ }^{\circledR}$ II PFGE apparatus (Bio-Rad Laboratories, Hercules, USA) at $6 \mathrm{~V} / \mathrm{cm}(200 \mathrm{~V})$ with $60-120$ switch time ramp for $24 \mathrm{~h}$. Yeast chromosome PFGE markers (Bio-Rad Laboratories, Hercules, USA) were used to allow estimation of phage genome size. 


\section{Bioinformatic Analysis}

The encoding potential of open reading frames (ORFs) was predicted with Glimmer (http://www.ncbi.nlm.nih.gov/ genomes/MICROBES/glimmer_3.cgi; Delcher et al., 1999) and GenemarkS (http://exon.gatech.edu/genemark/genemarks. cgi; Besemer et al., 2001). Possible functions of predicted proteins were predicted with BLASTP (http://blast.ncbi.nlm. nih.gov/Blast.cgi?PAGE=Proteins), Pfam (http://pfam.xfam. org/search\#tabview=tab1; Finn et al., 2015), HHpred (http:// toolkit.tuebingen.mpg.de/hhpred; Söding et al., 2005) and InterPro scan (http://www.ebi.ac.uk/interpro/search/sequencesearch; Mitchell et al., 2014). Molecular weights of predicted proteins were estimated using the batch protein molecular weight determination of the sequence manipulation suite (http:// www.bioinformatics.org/sms2/protein_mw.html). Detection of proteins with possible transmembrane domains and the lipoprotein cleavage signal was explored with TMHMM v.2 (http://www.cbs.dtu.dk/services/TMHMM/) and LipoP v.1 (http://www.cbs.dtu.dk/services/LipoP/), respectively (Käll et al., 2004; Rahman et al., 2008). Transfer RNA genes were predicted with tRNAscan-SE (http://lowelab.ucsc.edu/tRNAscan-SE/; Lowe and Eddy, 1997) and ARAGORN (http://130.235.46.10/ ARAGORN/; Laslett and Canback, 2004). Potential promoters were predicted by using extractUpStreamDNA (https://github. com/ajvilleg/extractUpStreamDNA) to extract $100 \mathrm{bp}$ of DNA sequence upstream of each gene and submitting all these sequences to MEME (Multiple Em for Motif Elicitation) (http://meme-suite.org/tools/meme; Bailey et al., 2009). Rhoindependent terminators were located with ARNOLD (http:// rna.igmors.u-psud.fr/toolbox/arnold/; Naville et al., 2011) with predictions being verified using Mfold Quikfold using RNA energy rules 3.0 (http://unafold.rna.albany.edu/?q=DINAMelt/ Quickfold; Zuker, 2003). Codon usage of CBB was analyzed using University of Georgia's amino acid and codon usage statistics services (http://www.cmbl.uga.edu/software/codon_ usage.html).

Coregenes (Turner et al., 2013) was used for total proteome comparisons between phages with the BLASTP threshold set at $75 \%$ and the terminal repeat ORFs, CBB_555 to CBB_605, of phage CBB being excluded. Genome comparison of the Rak2like phages was visualized using Easyfig (Sullivan et al., 2011) with comparison of genome sequences facilitated by TBLASTX (genomes were orientated such that the largest ORF's start codon was set to the first position to allow improved visual understanding as the starting point of all Genbank sequences was not uniform, with the terminal repeat of $\mathrm{CBB}$ also being excluded).

Phylogenetic analysis was conducted using MEGA version 7 (Kumar et al., 2016). Analysis using the portal vertex protein of phage $\mathrm{CBB}$ was conducted as described previously (Brewer et al., 2014). The full length protein was used in the BLASTP search to find phages with homologous portal proteins, taking a conserved internal region from 100 different portal vertex protein from different phages and aligned with MUSCLE. The resulting alignment was then used to create a phylogenetic tree based on the Maximum likelihood method (Jones et al., 1992) with 100 performed bootstraps.

\section{Phage CBB Virion ESI-MS/MS Proteome Analysis}

Phage capsid proteins were extracted from high titre $\mathrm{CsCl}$ purified phage $\left(>1 \times 10^{9} \mathrm{PFU} / \mathrm{mL}\right)$ using chloroform:methanol extraction $(1: 1: 0.75, \mathrm{v} / \mathrm{v} / \mathrm{v})$. The resulting protein pellet was resuspended in loading buffer (1\% SDS, 6\% sucrose, $100 \mathrm{mM}$ dithiothreitol, $10 \mathrm{mM}$ Tris $\mathrm{pH}$ 6.8, 0.0625\% w/v bromophenol blue) and heated to $95^{\circ} \mathrm{C}$ for $5 \mathrm{~min}$ to resuspend the pellet. This was subsequently loaded onto a $12 \%$ SDS-PAGE gel after which gel electrophoresis was conducted. The resulting gel was then stained using Gelcode ${ }^{\mathrm{TM}}$ Blue Safe Protein Stain (Thermo Scientific, Waltham, Massachusetts, United States) to visualize virion proteins. Gel fragments were extracted and subjected to trypsinization which were analyzed using tandem electrospray ionization-mass spectrometry (ESI-MS/MS) exactly as described previously (Van den Bossche et al., 2014).

\section{Accession Number}

The genome sequence of phage $\mathrm{CBB}$ has been submitted to Genbank under accession number KU574722.

\section{RESULTS AND DISCUSSION}

\section{Growth Parameters, Morphology, and Host Range}

Enterobacteria bacteriophage vB_PcaM_CBB was isolated from activated sludge from a waste water treatment plant in Little island, Co. Cork, Ireland. The bacterial host used was $P$. carotovorum sbp. carovotorum strain CBBL19-37-1 which had previously been isolated from blackleg-infected potato crop from Co. Cork. When the phage was plated and examined by plaque assay utilizing a $0.4 \%$ agar overlay, pinpoint sized plaques were observed with inconsistent formation across replicate experiments. This problem was overcome by using a $0.2 \%$ agarose overlay as described by Serwer et al. (2007). The host range of the phage was examined using a number of bacterial genera and species within the family Enterobacteriacea which showed it was capable of forming plaques on strains of $P$. carotovorum, Pectobacterium atrosepticum, Erwinia mallotivora, Cronobacter muytjensii, and Cronobacter malonaticus. The phage was also found to cause lysis-from-without on Dickeya dianthicola, Dickeya solani, Pantoea agglomerans, and Erwinia amylovora, as lysis was observed on low dilutions (neat, $10^{-1}$ ) of tested phage lysate with no plaque formation observed at subsequent higher dilutions (up to $10^{-8}$ ) (see Table 1).

Examination of morphology of $\mathrm{CBB}$ by transmission electron microscopy showed it belonged to the family of Myoviridae with an A1 morphotype (Ackermann, 2001), displaying large icosahedral heads presenting hexagonal and pentagonal outlines in micrographs (see Figure 1) from which estimations were made on its dimensions (see Table 2). Capsids had a height of $126.9 \pm 4.9 \mathrm{~nm}$ and a width of $128.0 \pm 6.2$ $\mathrm{nm}$. Tails displayed transverse striations with dimensions of $123.0 \pm 2.6 \times 27.1 \pm 1.8 \mathrm{~nm}$ with a base plate with dimensions of $36.4 \pm 2.3 \times 14.7 \pm 1.2 \mathrm{~nm}$. Phage CBB also possesses a neck passage structure (see triangle in Figures 1A,B,D-F) and 
TABLE 1 | Host range of bacteriophage vb_PcaM_CBB on 35 strains of various members of the bacterial family of Enterobacteriace as determined by spot testing with serial phage dilutions (the experiment was done twice: on separate days).

\begin{tabular}{|c|c|c|}
\hline Bacteria & Strain & Sensitivity \\
\hline Cronobacter muytjensii & ATCC 51329 (type strain) & 2 \\
\hline $\begin{array}{l}\text { Cronobacter } \\
\text { malonaticus }\end{array}$ & DPC 6531 & 2 \\
\hline Cronobacter sakazakii & ATCC 29004 & 0 \\
\hline $\begin{array}{l}\text { Dickeya chrysanthemi } \\
\text { biovar chrysanthemi }\end{array}$ & LMG 2804 (type strain) & 0 \\
\hline Dickeya dianthicola & PD 482 & 0 \\
\hline Dickeya dianthicola & PD 2174 & 1 \\
\hline Dickeya dianthicola & GBBC 1538 & 1 \\
\hline Dickeya solani & sp. PRI 2222 & 1 \\
\hline Dickeya solani & LMG 25865 & 1 \\
\hline Dickeya solani & GBBC 1502 & 1 \\
\hline Dickeya solani & GBBC 1586 & 1 \\
\hline Enterobacter cloacae & NCTC 11590 & 0 \\
\hline Enterobacter gergoviae & NCTC 11434 (type strain) & 0 \\
\hline Erwinia amylovora & LMG 2024 (type strain) & 0 \\
\hline Erwinia amylovora & GBBC 403 & 1 \\
\hline Erwinia mallotivora & LMG 1271 & 2 \\
\hline Pantoea agglomerans & LMG 2660 & 1 \\
\hline Pantoea agglomerans & LMG 2570 & 0 \\
\hline Pantoea stewartii & LMG 2713 & 0 \\
\hline Pantoea stewartii & LMG 2714 & 0 \\
\hline Pantoea stewartii & LMG 2712 & 0 \\
\hline $\begin{array}{l}\text { Pectobacterium } \\
\text { atrosepticum }\end{array}$ & DSM 18077 (type strain) & 0 \\
\hline $\begin{array}{l}\text { Pectobacterium } \\
\text { atrosepticum }\end{array}$ & DSM30186 & 2 \\
\hline $\begin{array}{l}\text { Pectobacterium } \\
\text { atrosepticum }\end{array}$ & CB BL5-1 & 1 \\
\hline $\begin{array}{l}\text { Pectobacterium } \\
\text { atrosepticum }\end{array}$ & CB BL7-1 & 1 \\
\hline $\begin{array}{l}\text { Pectobacterium } \\
\text { atrosepticum }\end{array}$ & CB BL11-1 & 1 \\
\hline $\begin{array}{l}\text { Pectobacterium } \\
\text { atrosepticum }\end{array}$ & CB BL12-2 & 1 \\
\hline $\begin{array}{l}\text { Pectobacterium } \\
\text { atrosepticum }\end{array}$ & CB BL13-1 & 1 \\
\hline $\begin{array}{l}\text { Pectobacterium } \\
\text { atrosepticum }\end{array}$ & CB BL14-1 & 1 \\
\hline $\begin{array}{l}\text { Pectobacterium } \\
\text { atrosepticum }\end{array}$ & CB BL15-1 & 1 \\
\hline $\begin{array}{l}\text { Pectobacterium } \\
\text { atrosepticum }\end{array}$ & CB BL16-1 & 2 \\
\hline $\begin{array}{l}\text { Pectobacterium } \\
\text { carotovorum sbp. } \\
\text { carovotorum }\end{array}$ & DSM 30168 (type strain) & 0 \\
\hline $\begin{array}{l}\text { Pectobacterium } \\
\text { carotovorum sbp. } \\
\text { carovotorum }\end{array}$ & DSM 30169 & 0 \\
\hline $\begin{array}{l}\text { Pectobacterium } \\
\text { carotovorum sbp. } \\
\text { carovotorum }\end{array}$ & DSM 30170 & 0 \\
\hline $\begin{array}{l}\text { Pectobacterium } \\
\text { carotovorum sbp. } \\
\text { carovotorum }\end{array}$ & CB BL19-1-37 & 2 \\
\hline
\end{tabular}

Results were recorded as 2 (plaque formation), 1 (lysis-from-without) and 0 (no sensitivity). beneath the base plate a set of six short tail fibers (length $28.6 \pm$ $2.7 \mathrm{~nm}$ ) could also be visualized (see arrow in Figures 1A,B,E). Phage particles with contracted tail sheaths were only rarely found indicating a high structural stability of the phage (Figure 1F). A low number of separated phage tails without a capsid was also detected (still decorated with hairy appendices and neck passage structure (see Figure 1E). The contractile tail of CBB was found to be highly unusual as it possesses hair-like appendages (whiskers) covering its surface (see open arrows in Figures 1B-D). These hairs (length $119.3 \pm 10.4 \mathrm{~nm}$ ) are highly stable, as they did not dissociate from the phage tails during a $1 \frac{1 / 2}{2}$ year of storage at $4^{\circ} \mathrm{C}$. Only two other phages have been reported to possess these hairy features; these being Escherichia coli phage PhAPEC6 (Tsones, 2014) and an unpurified phage observed in a preparation of crushed silkworm larvae referred to as $\mathrm{X}$ particle (Ackermann et al., 1994). Other than CBB having the whiskers, its morphology is typical of the Rak2-like phages in that it has a very large head with a comparatively short tail (Drulis-Kawa et al., 2014).

\section{General Genome Features}

Phage CBB was found to possess a very large genome of 355,922 bp with predicted terminal repeats of 22,456 bp (resulting in a total genome size of $378,378 \mathrm{bp}$ ). The existence of terminal repeats was suggested during sequence analysis by the identification of a localized area in the genome which had twice the read depth compared with the rest of the genome. Identification of phage genome ends by this approach has been reported for other phages (Fouts et al., 2013; Li et al., 2014). The existence of the terminal repeats was verified by PFGE, which indicated that the size of genome obtained from sequencing is within the correct range (Figure 2). However, even when terminal repeats are excluded, the genome is the third largest published phage genome to date, behind B. megaterium phage G (497,513 bp) and Cronobacter sakazakii phage vB_CsaM_GAP32 (358,663 bp) (Abbasifar et al., 2014).

The average $\mathrm{G}+\mathrm{C}$ content of the genome of $\mathrm{CBB}$ is $36 \%$ with below-average skews appearing around ORFs on the minus strand (see Figure 3). The average $\mathrm{G}+\mathrm{C}$ content is much lower than that typically found in its hosts species namely, $P$. atrosepticum at 50-51\% (Bell et al., 2004; Nikolaichik et al., 2014), Pectobacterium carotovorum sbp carotovorum at $52.2 \%$ (Park et al., 2012) and E. mallotivora at 52.4\% (Redzuan et al., 2014). This observation is not as unusual, as virulent phages will usually deviate from their host $\mathrm{G}+\mathrm{C}$ content having a higher $\mathrm{A}+\mathrm{T}$. It has been suggested that this is due to energy and metabolism cost limitations (Rocha and Danchin, 2002). However, the G+C content is quite similar to other Rak2-like phages (35.5, 34.09, and $35.5 \%$ for GAP32, PBECO4, and Rak2, respectively).

The genome of CBB has 554 predicted Open Reading Frames (ORFs) (excluding 51 ORFs within the predicted terminal repeat), of which only 34 are encoded on the minus strand. Twenty two ORFs were found to share sequence homology with each other suggesting that these potential genes arose from duplication events (paralogs) (see Supplementary S2, Table S1). On the basis of (i) observed protein sequence homologies, (ii) protein structure homology, (iii) lipoprotein, and (iv) 

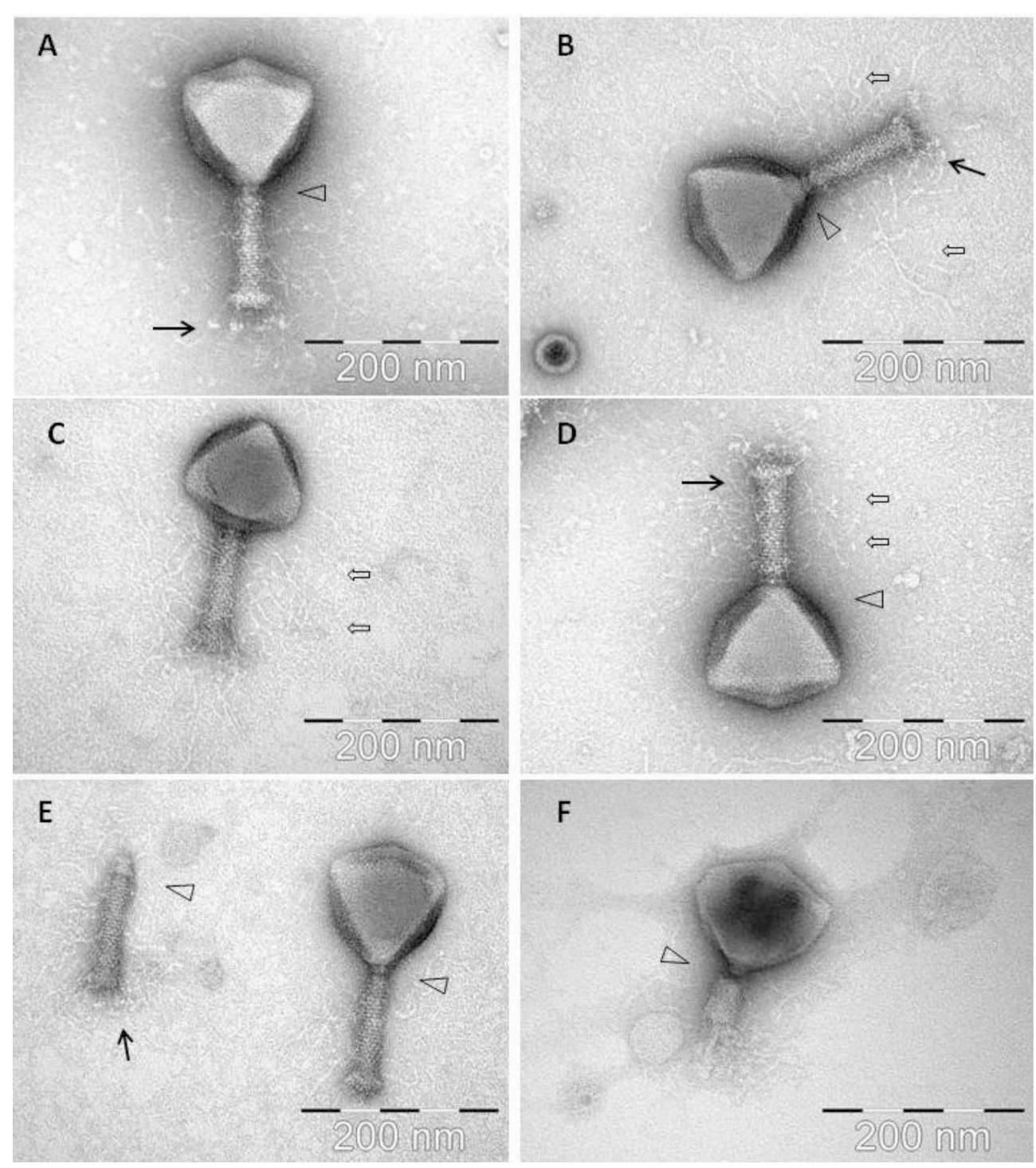

FIGURE 1 | Electron micrographs of phage CBB with black arrows indicating baseplate fibers, open arrows indicating hair-like appendages (whiskers) and triangles indicating neck passage structure. $(\mathbf{A}, \mathbf{B}, \mathbf{E}) \mathrm{CBB}$ virion base plate tail fibers are indicated. (B-D) Fully intact virions with atypical whisker-like structures on the contractile tail surface. (E) CBB virion contractile tail missing a capsid. (F) CBB virion with contracted tail.

TABLE 2 | Estimations of the dimensions of Enterobacteria phage vB_Pca_CBB derived from micrographs obtained from transmission electron microscopy.

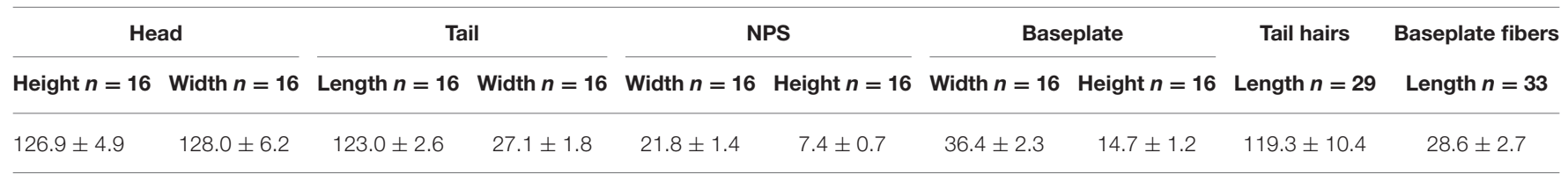

Tail length: incl. NPS (collar) structure and incl. baseplate (but without bp fibers).

Tail hairs: measured from flanking tail sheath surface and incl. tiny terminal globular structures.

Bp fibers: measured incl. terminal globular structures.

transmembrane analysis it was possible to predict the possible role for 162 of these proteins (see Supplementary S3, Table S1) with several others being categorized as hypothetical proteins
(47), conserved hypothetical proteins (291), putative lipoproteins (4), and putative membrane proteins (7) or conserved putative membrane proteins (43). No integrase, excisionase or repressor 


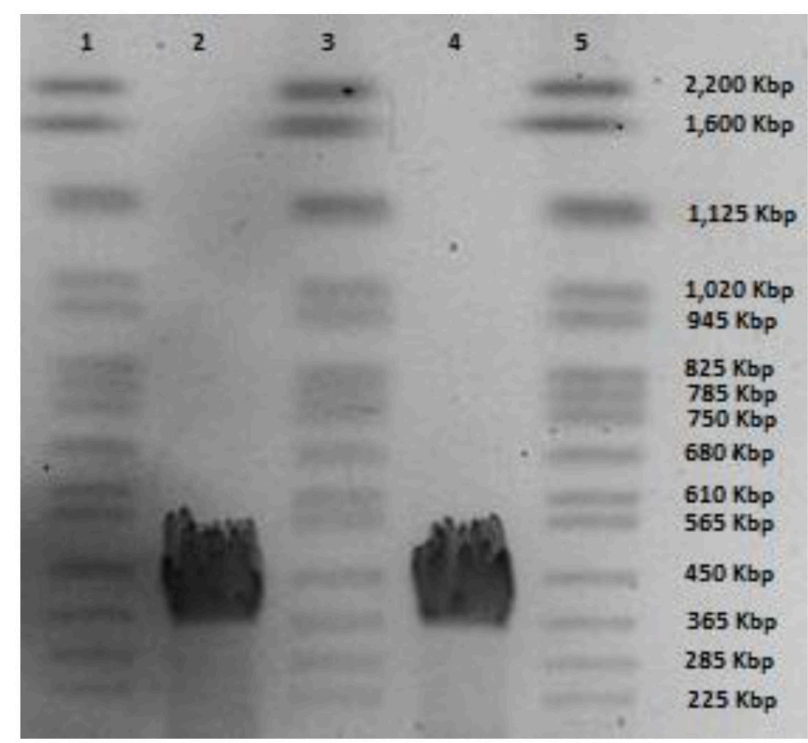

FIGURE 2 | PFGE of phage CBB genomic DNA; lanes 1, 3, and 5 yeast chromosome PFG marker (Bio-Rad Laboratories) and lane 2 and 4 genomic DNA of phage CBB.

genes were detected in the genome which suggests that this phage follows an exclusively lytic lifestyle.

It is understood that virulent phages can overcome codon utilization differences from their hosts by using encoded tRNAs, a feature often observed in large genomes (Mesyanzhinov et al., 2002). Phage CBB has a large number of predicted tRNA genes with a possible 33 being identified and concentrated within a $\sim 51 \mathrm{kbp}$ region within the genome. Thirty one of these genes appear to encode functional tRNA genes, with many of the tRNAs being for amino acids with codons which are highly utilized by the phage (see and Supplementary S2, Table S4 and Supplementary S4, Table S1).

\section{Phage CBB: A Rak2-like Phage and Its Distant Relationship to the Tevenvirinae Subfamily}

Initial BLASTP searches with the predicted ORFs of phage CBB showed that it shared strong homology with the Rak2like phages. Comparisons among these phages showed that the closest relative to $\mathrm{CBB}$ is C. sakazaki phage GAP32 (358,663 bp; 545 ORFs), with 479 homolog proteins followed by $E$. coli 121Q (348, 532; 611 ORFs) with 239 homolog proteins, E. coli PBECO4 (348,113 bp; 551 ORFs) with 230 homolog proteins and Klebsiella phage RAK2 (345,809 bp; 554 ORFs) with 230 homolog proteins. Phage $\mathrm{CBB}$ also shares strong homology with Klebsiella phage K64-1 (346,602 bp), however, at present its Genbank file contains an incomplete annotation (see Figure 3). Comparison between the proteomes of these phages shows that they share between 33 and 38\% of their proteins (204 homologous proteins). These shared proteins likely represent the core genome of the Rak2-like phages, given that they appear to be resistant to sequence deviation and horizontal gene exchange due to their importance for successful phage infection.

It has been reported that the Rak2-like phages possess a number of proteins that are homologous to those found within the superfamily of T4-like phages (Šimolūnas et al., 2013; Abbasifar et al., 2014). Total protein comparisons of phages CBB, GAP32, PEBEC04, RAK2 with phage T4 (NC_000866) and phage KVP40 (NC_005083.2) show that they share 41 homologous proteins with T4 $(14.75 \%$ of the total proteins of T4) and 46 homologous proteins with KVP40 (12.07\% of the total proteins of KVP40) at BLASTP cut value of $75 \%$. However, despite this correlation to the Tevenvirinae subfamily it is clear that the vast differences suggest these phages should be grouped separately. Nevertheless, a clear evolutionary link is present. There are 38 proteins which are considered to be the core proteins of the T4-like viruses. These proteins range in function from DNA replication, repair and recombination, auxiliary metabolism, gene expression and phage morphogenesis (Petrov et al., 2010). Examination of the CBB genome revealed that it has ORFs for proteins that appear to be homologs to these core proteins, with 21 being identified with functions involved in DNA replication and recombination, auxiliary metabolism as well as phage morphogenesis proteins with homology to those of T4 and KVP40 (reference strains for T4likevirus and Schizot4virus, respectively). However, large divergence was observed, especially with morphologically-related proteins, with some having very little homology to those of the reference strains (see Table 3). As well as T4-like core genes, there are a number of genes that have been designated at T4-like quasicore genes. These are genes whose presence will vary from phage to phage as it is believed that they are not necessary in certain genetic backgrounds (Petrov et al., 2010). In the genome of $\mathrm{CBB}$ it was also possible to identify 12 ORFs specifying putative homologs of these quasicore proteins (see Supplementary S2, Table S2).

To further investigate the relationship between $\mathrm{CBB}$ and the other Rak2-like phages and the T4-like phages, the amino acid sequence of portal vertex protein (CBB_252) of CBB was used to construct a phylogenetic tree using the top BLASTP hits against CBB_252 (see Supplementary S2, Table S3). The portal vertex protein has been used as marker in a number of phylogenetic studies of the T4-like phages (Zhong et al., 2002; Sullivan et al., 2008; Brewer et al., 2014). This tree placed CBB and the other Rak2-like portal proteins within a well-supported clade showing large divergence from clades representing the Tevenvirinae genera of T4likevirus, Schizot4likevirus and clades representing other unclassified T4-like phages. The result suggests that the Rak2-like phages are highly distinct from T4-like phages for which sequence data is available in the public databases (see Figure 4). The major capsid protein has also been used to conduct similar phylogenetic studies within the T4-like phages (Comeau and Krisch, 2008). A similar phylogenetic study was done with the major capsid protein of CBB (CBB_257) which also suggested the same conclusion to that obtained with the portal vertex protein (see Supplementary S2, Figure S1). 

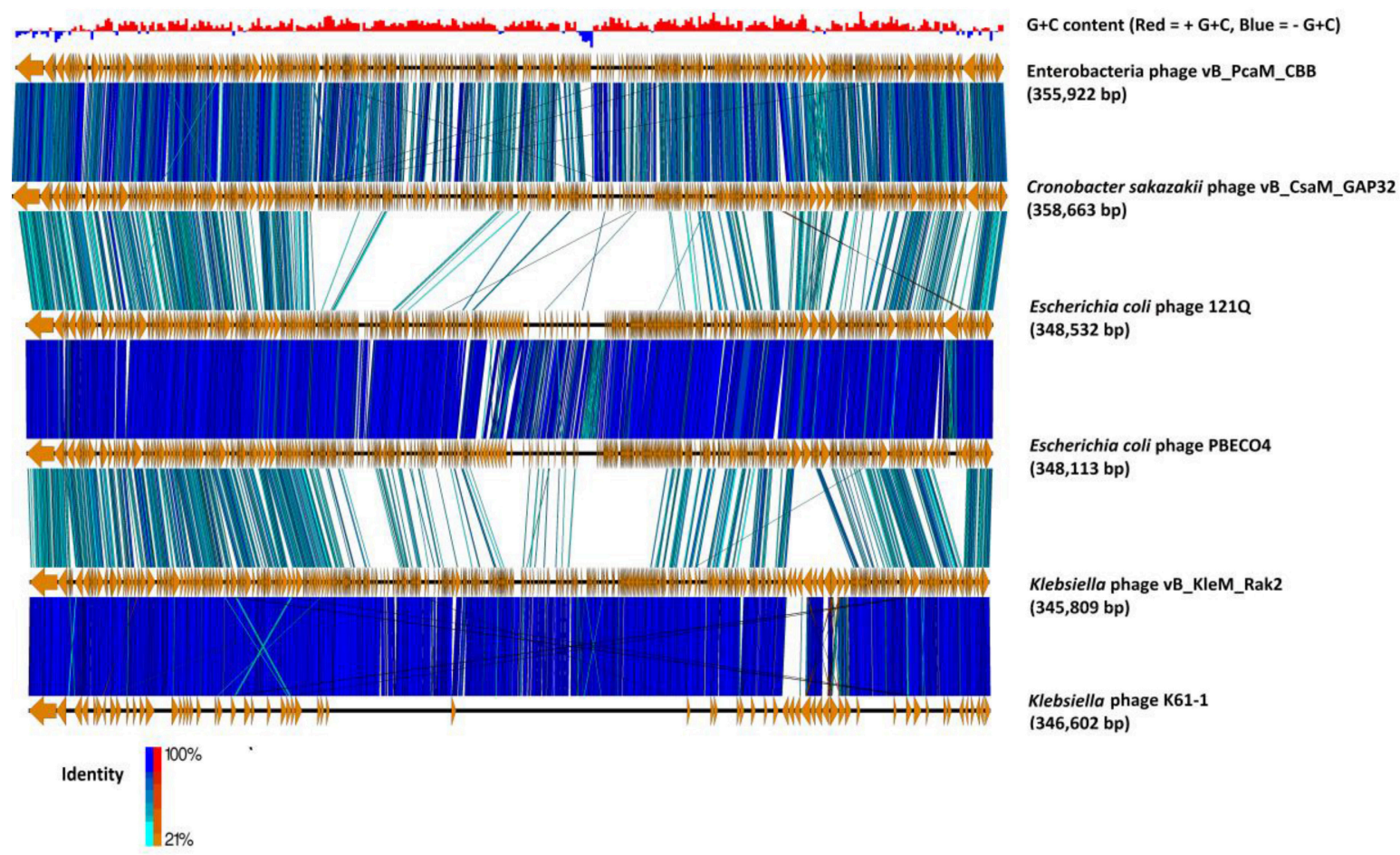

(358,663 bp)

Escherichia coli phage $121 \mathrm{Q}$

(348,532 bp)

Escherichia coli phage PBECO4

(348,113 bp)

Klebsiella phage vB_KleM_Rak2 $(345,809$ bp)

Klebsiella phage K61-1 $(346,602$ bp)

FIGURE 3 | Comparison of the genomes of phage CBB (without predicted terminal repeat region) to other potential Rak2-like phages (Cronobacter sakazakii phage vB_CsaM_GAP32, Escherichia coli phage 121Q, E. coli phage PBECO4, Klebsiella phage vB_KleM_RAK2, Klebsiella phage K64-1) using currently available annotations employing TBLASTX and visualised with Easyfig (Sullivan et al., 2011). A bar chart shows the G+C skew of the CBB genome, genome maps comprise of orange arrows indicating locations of genes among the different phage genomes; and lines between genome maps indicate level of homology (blue/turquoise-genes sharing orientation, red/orange-genes in inverted orientation). To assist in the comparison between genomes the largest gene of each of the phages was positioned as the first gene for each genome.

\section{Transcription}

Within the genome of $\mathrm{CBB}$, eighteen RpoD-like promoters were predicted with a consensus sequence preceded by an UPlike element (Estrem et al., 1998; see Supplementary S2, Table S5). Eleven of these promoters were concentrated in a region upstream of ORFs CBB_390-546, with the majority of ORFs within this region encoding short hypothetical proteins (see Figure 4 part A). Of the few ORFs for proteins of known function, two are most likely to be involved in overriding of the host transcription: the transcriptional regulator (CBB_511) and RNA polymerase sigma factor (CBB_513). The RNA polymerase sigma factor contains a RNA polymerase -70 like domain (IPR014284) containing sigma factor region 2 (IPR013325), region 3 and region 4 (IPR013324). Protein CBB_476 may also have a role in overriding host transcription due to a PrlF antitoxin family domain (IPR031848). It is suspected that the mentioned region CBB_390-CBB_546 represents the early genes which are expressed in the very early stages of infection and are involved in host take over. It should also be noted that three of the other seven RpoD-like promoters lie on the terminal repeat downstream of this region and could possibly be a continuation of the early gene region with the remaining promoters being located on the opposite end of the genome (see Figure 5 part B).
Aside from this RpoD-like promoter, a second possible promoter was detected which shows resemblance to a classic RpoD-like promoter with a classic -10 region (TATA). However, it differs with its -35 region with a consensus sequence of TGAAACG instead of TTGACA (see Supplementary S2, Table S6). This motif was also identified in the GAP32 genome (Abbasifar et al., 2014). Of the 18 examples of this detected motif, 11 were upstream of ORFs CBB_258-CBB_329 (see Figure 5 part B), with many of the ORFs within this region found to encode proteins with functions related to DNA synthesis (CBB_263, 280, 328, 290, 291, 315, 277, 324, and 325). There was also a T4-like gp55-like sigma factor (PHA02547, 4.69e08) predicted for possible late transcription (CBB_244) just downstream of one of these promoters (Porf_244). However, no homologs for the other associated late transcription proteins of phage T4, namely gp33 and gp45, were detected (Geiduschek and Kassavetis, 2010).

A third potential promoter was found by analyzing the upstream sequences of ORFs that had been predicted to encode structure-related proteins of $\mathrm{CBB}$ in a single submission to MEME. Analysis showed the presence of a consensus sequence of ATAAATA with a concentration of $\mathrm{A}$ and $\mathrm{T}$ downstream of this motif. This hypothetical promoter was found to be present in 35 locations and has also been predicted to precede structural related 
TABLE 3 | Core proteins of T4-like phages identified within the CBB genome with full length sequence comparison to homologs in Enterobacter phage T4 and Vibrio phage KVP40 (reference strains of T4likevirus and Schizot4likevirus, respectively) using BLASTP.

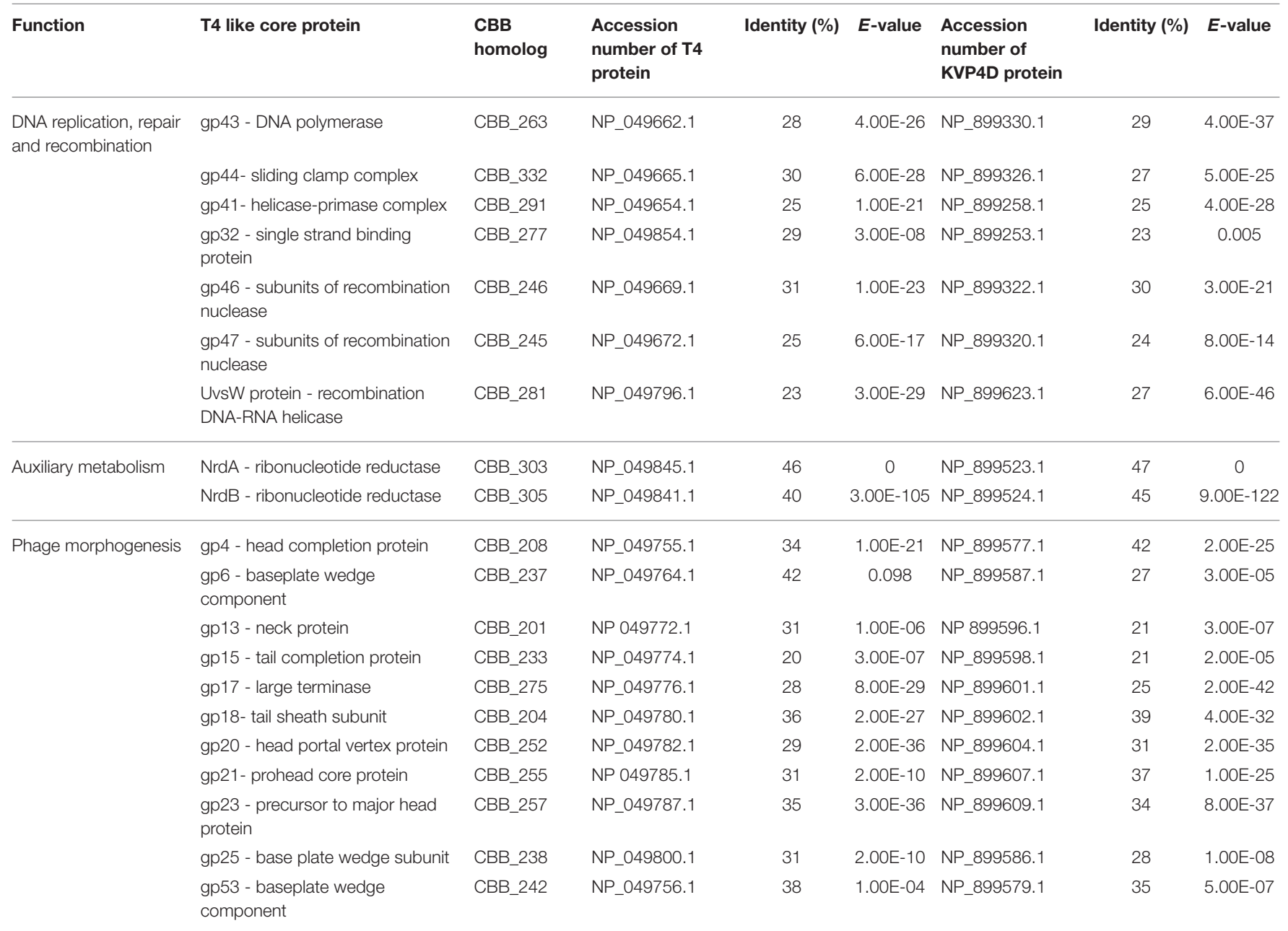

genes in GAP32. It is expected that this sequence plays a role in late gene expression (see Supplementary S2, Table S7). This motif resembles that of the T4 late promoter sequence, namely TATAAATA (Geiduschek and Kassavetis, 2010).

Apart from the above-mentioned promoters, 74 potential rho factor independent terminators were identified in the CBB genome (Supplementary S2, Table S8).

\section{DNA Replication, DNA Modification, and Nucleotide Metabolism}

There are eight proteins which form the T4 DNA replisome these being DNA polymerase (gp43), clamp loaders (gp44, gp62, and gp45), single strand DNA binding protein (gp32), primase (gp61), helicase (gp41), and loading protein (gp59) (Nelson et al., 2009). CBB was found to have homologs to five of the eight proteins (CBB_263, 332, 277, 290, and 291), but lacks the clamp loaders (gp62, gp45) and loading protein (gp59). Interestingly, the phage possesses a bacterial DNA polymerase
III epsilon subunit (CBB_280) with a DnaQ domain (4.32e21). There was also a protein which resembles the bacterial DNA polymerase III alpha subunit (CBB_328). However, this protein appears to be truncated, being much smaller in size to its closest bacterial hits on BLASTP (172aa vs. 1120aa) such as those from Oceanobacillus massiliensis (WP_010651140.1) and B. megaterium (WP_026681428.1).

The phage also has T4 homologs for helicase uvsw (CBB_281) and dda (CBB_315), topoisomerase gp52 (CBB_325), RNA ligase rnlA (CBB_83) and DNA ligase gp30 (CBB100), while one of its two ribonuclease $\mathrm{H}$ enzymes (CBB_272, 314) is related to $\mathrm{T} 4 \mathrm{rnh}$. In addition, an array of T4 homologs involved in DNA repair and recombination were identified, including gp46-gp47 (CBB_246,267), endonuclease VII (CBB_248), uvsX (CBB_278), uvxW (CBB_281) and UV repair endonuclease V (CBB_519). $\mathrm{CBB}$ also has other DNA-replication proteins that have no counterpart to phage T4 such as primase-helicase (CBB_291) and gyrase subunit (CBB_324).

Like the other Rak2-like phages, $\mathrm{CBB}$ has ORFs coding for a number of enzymes apparently involved in nucleotide 


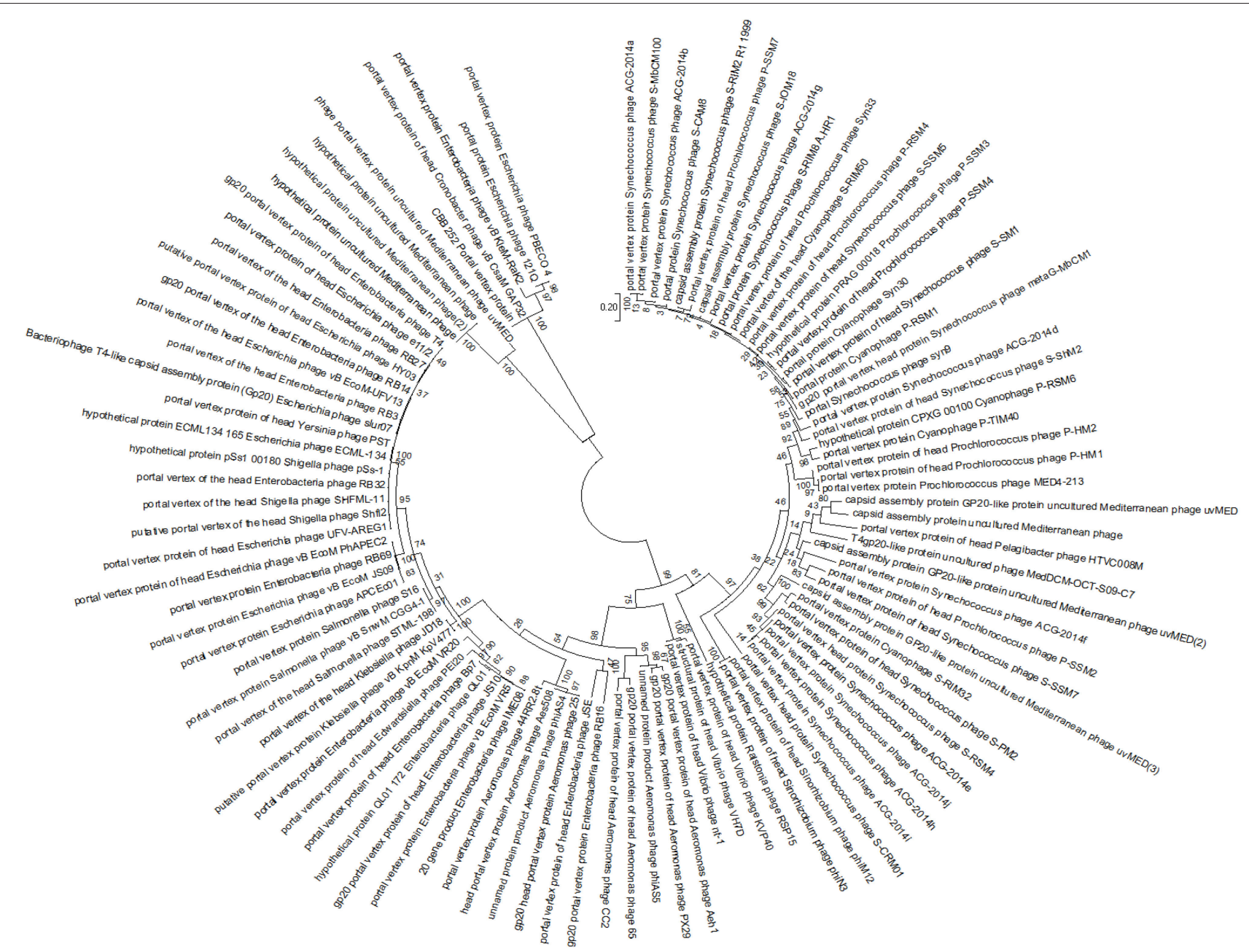

FIGURE 4 | Maximum likelihood tree created from the alignment of the conserved region of the portal vertex region of 100 homologous sequences from different T4-like phages to that of the portal vertex protein of phage CBB, found using a BLASTP search.

metabolism including the aerobic class I NrdA-NrdB (CBB_303, 305) and anaerobic class III NrdD-NrdG (CBB_141, 145) ribonucleotide reductase (RNR) enzymes for the conversion of ribonucleotides to deoxyribonucleotides (Dwivedi et al., 2013). There is also a glutaredoxin (CBB_194) to potentially support with class I RNR function (Sengupta and Holmgren, 2014). With the proteins CBB_141 and CBB_194, there are differences between phage T4 and CBB. The latter has an NrdD RNR subunit instead of the $\mathrm{NrdH}$ RNR subunit and glutaredoxin instead of thioredoxin. CBB has two CMP/dCMP deaminases (CBB_110,135). These generate dUMP, which is a substrate for its thymidylate synthase (CBB_223, T4 homolog td) which generates dTMP. The thymidylate synthase is supported by a dihydrofolate reductase (CBB_313, T4 homolog Frd), which provides the intermediate metabolite tetrahydrofolate. The phage has a thymidine kinase (CBB_203, T4 homolog tk) for the production of TMP, and such dNMPs may potentially be utilized by its deoxynucleoside-monophosphate kinase (CBB_203) for the production of dNDP derivatives. There is also a putative $5^{\prime}$,
3' deoxyribonucleotidase (CBB_380), an enzyme in humans and mice involved in the dephosphoration of dNMP (Walldén et al., 2007).

Like GAP32, CBB has genes that appear to encode possible nicotinamide-nucleotide adenylyltransferases (CBB_113, 361) as well as a gene encoding nicotinamide phosphoribosyltransferase (CBB_115). These enzymes are involved in the de novo synthesis of coenzyme $\mathrm{NAD}^{+}$(Schweiger et al., 2001) and their function is supported by a nicotinamide mononucleotide transporter [PnuC] (CBB_361), a membrane bound protein involved in the uptake of the $\mathrm{NAD}^{+}$precursor nicotinamide mononucleotide (Zhu et al., 1991).

DNA methylation and glycosylation are strategies used by phages to provide protection against host restriction (Samson et al., 2013). CBB possesses DNA methylation enzymes for both adenine and cytosine (CBB_72, 157, 399). However, unlike GAP32, CBB lacks a second copy of DNA N-6-adenine methyltranferase (GAP32_519). No genes for enzymes were identified in the $\mathrm{CBB}$ genome related to the production of 


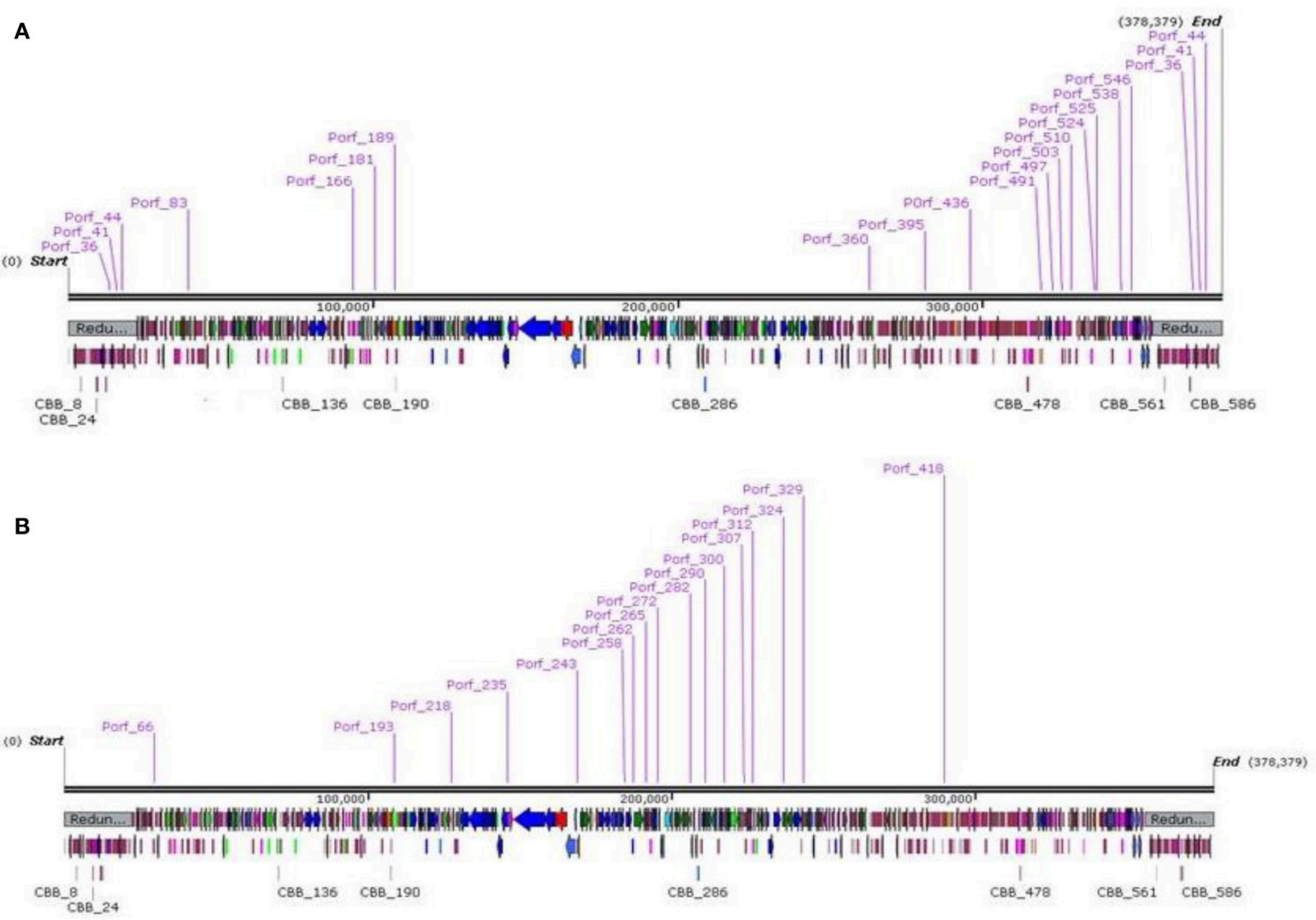

FIGURE 5 | Genome maps of bacteriophage CBB showing locations of RpoD-like promoters (A) and CBB divergent RpoD-like promoters (B) created using SnapGene.

glycosylated hydroxymethyl cytosine which are found in the T-even phages (Petrov et al., 2010).

\section{tRNA Gene and tRNA Related Protein}

Phage CBB has a large number of tRNA genes and it appears that in two cases (tRNA gene 13 and 22), correct formation and function of their tRNA gene products is assisted by tyrosyl tRNA synthetase (CBB_132) and tRNAHis guanylyltransferase (CBB_152) respectively, both of which are also encoded on the $\mathrm{CBB}$ genome. The phage also appears to assist in tRNA turnover with the capability of releasing tRNA molecules from newly formed peptides by a tRNA peptidyl-tRNA hydrolase (CBB_392). All three gene products have homologs present in GAP32 with just CBB_132 and CBB_392 being shared with Rak2 also. As mentioned CBB has two RNA ligase enzymes (CBB_83, 181) of these CBB_83 may be involved in tRNA repair (Wang et al., 2006).

\section{Translation and Post-translation}

The phage also appears to be able to assist in the formation of the bacterial translation initiation complex (ribosome, mRNA, and tRNA) by possessing its own translation initiation factor IF3 (CBB_318), with homologs of this protein also being identified in GAP32, 121Q, PBECO4, and Rak2. In addition, CBB has two ORFs encoding for GroES-like proteins (CBB_131,268). Large phages such as T4 and Enterobacter phage RB49 can use hostencoded co-chaperonin GroES to assist in the correct folding of their own structural proteins. However, these two phages also possess their own phage-encoded GroES-like proteins that can mimic bacterial host GroES proteins (Keppel et al., 2002), this may also be the case for CBB

\section{Terminase and DNA Packing}

Packaging of bacteriophage T4 DNA into its capsid requires two proteins; the small terminase (gp16) and the large terminase (gp17). Phage $\mathrm{CBB}$ has two proteins which possess the 17 terminase domain (PHA02533), namely CBB_274 (E-value 1.28e-09) and CBB_275 (E-value 5.47e-79). However, in the case of CBB_274 this domain is incomplete suggesting it to be a truncated form of a large terminase. This feature was also found to be present with the other Rak2-like phages and is considered to be unusual and has also been identified in the T4 superfamily Sinorhizobium phages phiM12 (NC_027204) and phiN3 (NC_028945).

The genomic DNA of phage T4 is packaged into its capsid with the headful packaging strategy, which results in a partially 
circularly permuted chromosome that is terminally repeated (Casjens and Gilcrease, 2009). The exact physical nature of the genome of $\mathrm{CBB}$ currently remains unknown; but as discussed previously, analysis of its genome sequence reads suggests the presence of terminal repeats.

CBB also has an ORF for a T4 homolog to endonuclease VII (CBB_248), which in T4 is involved in DNA packaging as well as recombination and mismatch repair.

\section{Selfish Genetic Elements}

Homing endonucleases are selfish mobile genetic elements with endonuclease activity that only promote the spread of their own encoded gene. These can be found as selfstanding genes within introns, as fusions with host proteins or also in self-splicing inteins and their presence is prevalent in a number of phage genomes (Edgell et al., 2010). In $\mathrm{CBB}$, three free-standing homing endonuclease genes of the $\mathrm{HNH}$ family were identified, namely homing endonucleases CBB_420, CBB_ 528, and CBB_535 resembling those found in bacteriophages Rak2 and GAP32. Homing endonuclease CBB_420 lies at the end of tRNA gene 7A, CBB_528 sits between a hypothetical and a putative membrane protein and CBB_535 lies at end of virion structural protein, Inteins are selfish genetic elements which self-cleave during protein posttranslation. These elements are typically spread by homing endonuclease elements (Tori and Perler, 2011). Nevertheless, no intein-related domains (hedgehog/Hint) were found in the genome of $\mathrm{CBB}$. However, it should be mentioned that inteins can occur in the Rak2-like phages with hedgehog/Hint domain (smart00306) in association with the domain of a homing endonuclease of the LAGLIDADG family (pfam14528). Both were detected in the large terminase of phages Rak2 and K64-1.

\section{Cell Wall Degrading Enzymes}

The $35.5 \mathrm{kDa}$ gene product of CBB_187 is predicted to be the endolysin of CBB with homologs identified in GAP32 (gp180), 121Q (gp532), and RAK2 (gp506). In silico analysis shows that the protein is modular in structure, possessing three domains, these being an N-terminal transmembrane domain, an intermediate domain with a possible cell wall-binding domain showing weak homology to the LysM domain (IPR018392), and a C-terminus lysozyme domain (IPR023347). It is worth mentioning that the cell wall binding domain is very apparent in the $121 \mathrm{Q}$ homolog (PB1_121_532) of this protein. The presence of a cell binding domain is unusual in phages infecting Gram-negative bacteria and only a few endolysins with this feature have been reported to date, examples being the Pseudomonas aeruginosa phage endolysins KZ144 (phage $\varphi \mathrm{KZ}$ ), and EL188 (phage EL) (Briers et al., 2009, 2007). However, the cell-binding domains of these differ to those identified in the Rak2-like phages. Another unusual feature of this endolysin is the presence of an N-terminal transmembrane domain, reported in endolysins that follow the signal arrest system, examples being P1 lyz and $\varphi \mathrm{KMV}$ gp45 lysin (Xu et al., 2004). Unsuccessful attempts to clone and express CBB_187 to date have suggested that it may be toxic, as induction results in inhibition of $E$. coli growth (data not shown).

Three identified proteins (CBB_238,239 and 240) are possibly associated with the baseplate structure of the phage tail; and each has a lysozyme domain. Gene product CBB_238 possesses a GPW 25-like domain (PF04965), which is related to gp25 of phage $\mathrm{T} 4$. The latter forms part of the $\mathrm{T} 4$ baseplate and possesses acidic lysozyme activity (Szewczyk et al., 1986), with protein CBB_238 also being quite similar in size (129 aa vs. 132 aa). Gene product CBB_239 has a T4-type lysozyme domain (IPR001165) and CBB_240 an N-terminal gp5 domain (IPR006531) with a Cterminal lysozyme (IPR002196). The gp5 N-terminal domain is an oligosaccharide-binding $(\mathrm{OB})$ fold and is related to the tail spike (gp5) of T4. However, it is not certain if CBB_250 has this function as it is much larger than gp5 (894aa vs. 575aa) and the domain architectures differs, with gp5 possessing an $\mathrm{N}$-terminal OB fold, centrally located lysozyme and C-terminal triple stranded-helix domains (Kanamaru et al., 2002). CBB_250 may also contain a centrally located M23 family peptidase domain (pfam01551, E-value 6.48E-4) which could be identified in homologs in other Rak2-like phages. Of these three proteins, only CBB_238 and CBB_240 have been confirmed as structural proteins in the Rak2-like phages.

\section{Structural Proteins of CBB and Other Rak2-Like Phages}

To identify gene products involved in the maturation and structure of the capsid of $\mathrm{CBB}$, an in silico approach was first undertaken to identify homologs of the proteins with known functions. This was followed by identification of proteins having domains with structure-related roles and also by protein analysis using mass spectrometry (ESI-MS/MS). The identification of phage structural homologs was supported by structural proteomic analysis data that had previously been conducted on other Rak2-like phages, namely GAP32 and Rak2 (Šimolūnas et al., 2013; Abbasifar et al., 2014). Using this approach, it was possible to predict 65 gene products with structural roles (excluding the terminase proteins as well as the PhoH and ssDNA binding protein of Rak2). Such genes were identified to have functions in the structure of the capsid (CBB_208, 252, 255, 257), neck (CBB_201), tail (CBB_112, 204, 233), baseplate (CBB_237, 238, 239, 240, 242), and tail fibers (CBB_226, 260, 261). Next we attempted an experimental verification of structural proteins using SDS-PAGE of the denatured virion proteins (see Figure 6), followed by trypsin digestion and mass spectrometry. From this work, 55 proteins were associated with the structure of the phage capsid (see Table 4) with sequence coverage ranging from 4.1 to $91.3 \%$ and the number of unique peptides ranging from 1 to 30. These results allowed the identification of an additional 18 structural gene products to be associated with the structure of the mature CBB phage particle (see Supplementary S5, Table S1 and Supplementary S6).

The structure of CBB is very similar to that of GAP32, sharing 76 homologs of the 83 gene products predicted to be involved in CBB morphology. Phage Rak2 however, is less similar to CBB, only sharing 64 homologs of these genes. TEM images taken of 


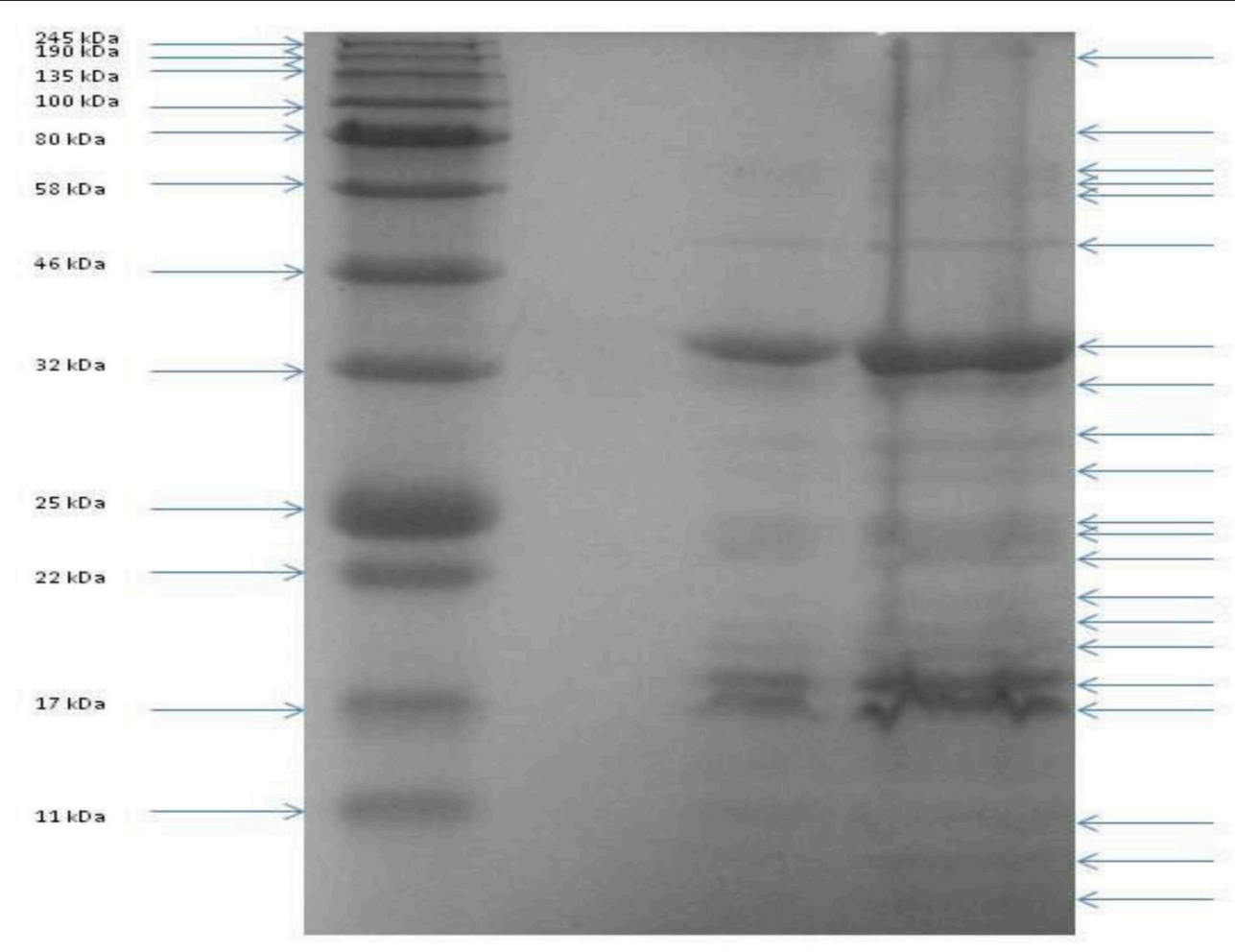

FIGURE 6 | SDS PAGE of the structural proteins of phage vB_PcaM_CBB. Left lane shows migration patterns of New England Biolab's coloured molecular mass board range protein standard with right lanes showing that of structural proteins of phage CBB.

these phages shows that tail fibers associated with the baseplates of CBB and GAP32 are morphological very similar with both greatly differing to that of Rak2 (Šimolūnas et al., 2013; Abbasifar et al., 2014). Analysis of the structural genes also indicates this. There are tail fiber related genes (CBB_226, 261) in the genomes of GAP32 and CBB which have no homologs in Rak2 and there are also a number of tail fiber/tail spike gene products (RAK_527, 528, 530, 530, 532) in Rak2 which are not represented in CBB and GAP32. These differences most likely represent adaption of tail components correlating with host ranges of these phages.

The only structural protein of GAP32 that had previously been identified by mass spectrometry, which was not found in the genome of CBB, was GAP_001. It resembles a DNA chromosome condensation protein. This protein possesses the AST1 (COG5184) domain of the Conserved Domain Database and the regulator of chromosome condensation 1/ beta-lactamase-inhibitor protein II (IPR009091) domain of Interproscan. Interestingly homologs of this protein were also identified in multiple copies in the genomes of other Rak2-like phages 121Q (121Q_234-238, 240242, and 244-248) and PBEC04 (ACQ_286, 289, 292, and 294-296).

The majority of the structural genes of CBB found within one large region of approximately $70 \mathrm{kbp}$ (CBB_201-261), with small clusters of genes occurring throughout the rest of the genome. There are six structural proteins (CBB_144, 247, 536, 537, 551, and 552) that have been identified by mass spectrometry whose genes are not present on GAP32 genome, and four of these occur in a small $\sim 10 \mathrm{kbp}$ cluster (CBB_534-553).

One of the unusual features found with phage $\mathrm{CBB}$ when compared to GAP32 was a number of proteins containing Kelch-like domains for which there were no obvious homologs present in the other Rak2-like phages. These proteins were CBB_550, possessing a Kelch-type beta propeller (IPR015915) domain and CBB_552 and CBB_554, both with a Kelch-type beta propeller (IPR015915) and Kelch repeat type 1 (IPR006652) domains. These domains are comprised of six four-stranded beta propellers and have been identified as important in proteinbinding interactions in a number of non-phage-related proteins. Of the three mentioned proteins, CBB_552 has been identified to form part of the mature phage structure. Proteins containing Kelch-like domains have been identified in the proteomes of eukaryotic viruses such as poxvirus. Their presence is unusual in phage but they have been reported in other giant phages that infect Pseudomonas and Yersinia (Hertveldt et al., 2005; Barry et al., 2010; Skurnik et al., 2012).

Given the high level of morphological and genetic similarity of phage CBB-GAP32, it is logical to assume that the presence of the extra morphological feature of hair-like structures along the tail shaft of phage CBB would be represented by morphological genes not present in GAP32 (other than CBB_370, a homolog of which is found in Rak2), if GAP32 does indeed lack these atypical whisker-like structures observed on CBB. However, it is still possible that a number of other structural proteins of $\mathrm{CBB}$ may not have been detected in the mass spectrometry assays 
TABLE 4 | Details of the proteins identified from ES-MS/MS conducted on capsid proteins of phage CBB.

\begin{tabular}{|c|c|c|c|}
\hline ORF & Predicted function & $\begin{array}{c}\text { Number of } \\
\text { unique peptides }\end{array}$ & $\begin{array}{l}\text { Sequence } \\
\text { coverage } \%\end{array}$ \\
\hline CBB_29 & Structural protein & 8 & 29.55 \\
\hline CBB_38 & Structural protein & 9 & 56.61 \\
\hline CBB_104 & $\begin{array}{l}\text { ATP-dependent Clp } \\
\text { protease proteolytic } \\
\text { subunit }\end{array}$ & 1 & 4.51 \\
\hline CBB_112 & Major tail protein & 4 & 24.30 \\
\hline CBB_118 & Structural protein & 7 & 60.40 \\
\hline CBB_144 & Structural protein & 5 & 34.00 \\
\hline CBB_169 & Structural protein & 3 & 26.30 \\
\hline CBB_183 & Structural protein & 8 & 23.60 \\
\hline CBB_201 & Neck protein & 5 & 32.60 \\
\hline CBB_205 & Structural protein & 6 & 20.10 \\
\hline CBB_207 & Structural protein & 9 & 37.10 \\
\hline CBB_210 & Structural protein & 13 & 60.50 \\
\hline CBB_213 & Structural protein & 5 & 18.93 \\
\hline CBB_214 & Structural protein & 1 & 15.40 \\
\hline CBB_224 & Structural protein & 22 & 47.80 \\
\hline CBB_225 & Structural protein & 16 & 68.54 \\
\hline CBB_226 & $\begin{array}{l}\text { Long tail fiber proximal } \\
\text { subunit }\end{array}$ & 10 & 6.06 \\
\hline CBB_227 & Structural protein & 5 & 32.07 \\
\hline CBB_228 & Structural protein & 13 & 44.09 \\
\hline CBB_230 & Structural protein & 2 & 12.70 \\
\hline CBB_231 & Structural protein & 12 & 53.30 \\
\hline CBB_233 & $\begin{array}{l}\text { Tail sheath stabilizer and } \\
\text { completion protein }\end{array}$ & 12 & 31.61 \\
\hline CBB_234 & Structural protein & 12 & 35.84 \\
\hline CBB_236 & Structural protein & 21 & 7.72 \\
\hline CBB_237 & Baseplate wedge & 13 & 12.47 \\
\hline CBB_240 & $\begin{array}{l}\text { Baseplate hub subunit } \\
\text { and tail lysozyme }\end{array}$ & 3 & 4.11 \\
\hline CBB_241 & Structural protein & 12 & 17.10 \\
\hline CBB_242 & Baseplate wedge protein & 3 & 39.40 \\
\hline CBB_243 & Structural protein & 8 & 46.20 \\
\hline CBB_247 & Structural protein & 1 & 4.78 \\
\hline CBB_251 & Structural protein & 29 & 50.14 \\
\hline CBB_254 & Structural protein & 3 & 15.50 \\
\hline CBB_256 & Structural protein & 4 & 13.23 \\
\hline CBB_257 & $\begin{array}{l}\text { Precursor of major head } \\
\text { subunit }\end{array}$ & 21 & 68.06 \\
\hline CBB_260 & Putative tail fiber protein & 11 & 24.04 \\
\hline CBB_270 & Structural protein & 12 & 91.32 \\
\hline CBB_271 & Structural protein & 9 & 56.40 \\
\hline CBB_276 & Structural protein & 8 & 21.70 \\
\hline CBB_286 & Structural protein & 4 & 29.70 \\
\hline CBB_292 & Structural protein & 1 & 10.90 \\
\hline CBB_294 & Structural protein & 4 & 33.10 \\
\hline CBB_298 & Structural protein & 10 & 35.81 \\
\hline CBB_299 & Structural protein & 2 & 20.00 \\
\hline CBB_320 & Structural protein & 4 & 37.20 \\
\hline
\end{tabular}

(Continued)
TABLE 4 | Continued

\begin{tabular}{llcc}
\hline ORF & Predicted function & $\begin{array}{c}\text { Number of } \\
\text { unique peptides }\end{array}$ & $\begin{array}{c}\text { Sequence } \\
\text { coverage \% }\end{array}$ \\
\hline CBB_322 & Structural protein & 30 & 43.57 \\
CBB_334 & Structural protein & 7 & 40.00 \\
CBB_494 & Structural protein & 1 & 5.81 \\
CBB_496 & Structural protein & 4 & 17.50 \\
CBB_536 & Structural protein & 8 & 41.40 \\
CBB_537 & Structural protein & 2 & 11.00 \\
CBB_548 & Structural protein & 5 & 25.90 \\
CBB_549 & Structural protein & 6 & 50.70 \\
CBB_551 & Structural protein & 4 & 24.10 \\
CBB_552 & Structural protein & 2 & 9.54 \\
CBB_553 & Structural protein & 7 & 34.80 \\
\hline
\end{tabular}

conducted for this article. At this time, it is not possible to pinpoint the exact gene products responsible for the atypical whisker-like structures observed in phage CBB.

\section{CONCLUSION}

A number of jumbo phages like CBB have been reported in recent years (Kim et al., 2013; Šimolūnas et al., 2013; Abbasifar et al., 2014; Drulis-Kawa et al., 2014; Buttimer et al., 2016; Yuan and Gao, 2016). Among them, phage CBB is significant given the identification of atypical whisker-like structures on its contractile tail, for which a function has not yet been assigned. However, given that a number of proteins found on phage particle surfaces (such as those with Ig-like domains, Fraser et al., 2006) have been proposed to play a role in the interaction between the phage and the host cell surface other than tail fiber proteins, it is not difficult to hypothesize that the whisker-like structures may play a similar role. However, this remains to be proven. The likely reason that these phages have been rarely isolated and reported may be due to the difficulty observed with plaque formation in standard plaque assay overlays, as experienced with phage CBB.

$\mathrm{CBB}$ is a member of a group of phages represented by phage Rak2 (the first to have been reported), of which, phages GAP32, PBEC03, 121Q, and K61-1 are members. CBB, like the other Rak2-like phages possesses a number of homologous core proteins found in T4-like phages, a number of which play crucial functions, suggesting that these proteins have not been acquired by horizontal gene transfer as seen with some phages (Petrov et al., 2010). However, given the level of divergence and the lack of a number of core T4-like protein homologs, this relationship appears to be distant with current members of Tevenvirinae, as suggested by the phylogenetic analysis of portal vertex and major capsid proteins done in this study. In addition, these phages also possess a large number of proteins that have not been identified in other T4-like phages, as illustrated with total protein comparison of the Rak2-like phages to those of phage T4 and KVP40.

With the sequence annotation and morphological data currently available for these phages, it is justifiable that 
they would form their own genus ("Rak2virus") without any question; and indeed the proposal of placing them within a new subfamily has very strong merit, as suggested by Abbasifar et al. (2014). Nevertheless, it must be mentioned that the putative functions of the CBB genes/proteins described in this work is based on gene identification and similarity to genes/proteins of other phages in the public databases. In vivo work would be useful to fully validate their precise roles.

\section{AUTHOR CONTRIBUTIONS}

$\mathrm{CB}$, did the main body of research and wrote this article; $\mathrm{HH}$, contributed to the mass spec work; $\mathrm{HO}$, contributed to the sequencing of the phage genome; ACa, contributed to the PFG; $\mathrm{HN}$, contributed to the TEMs; OM, contributed to the PFG; RR, edited article; $\mathrm{CH}$, edited article; JN, contributed to the mass spec work; JM, edited article; RL, contributed to the sequencing and mass spec work; ACo edited and financed the publication.

\section{REFERENCES}

Abbasifar, R., Griffiths, M. W., Sabour, P. M., Ackermann, H. W., Vandersteegen, K., Lavigne, R., et al. (2014). Supersize me: Cronobacter sakazakii phage GAP32. Virology 460-461, 138-146. doi: 10.1016/j.virol.2014.05.003

Ackermann, H. W. (2001). Frequency of morphological phage descriptions in the year 2000. Brief review. Arch. Virol. 146, 843-857.

Ackermann, H. W., Auclair, P., Basavarajappa, S., Konjin, H. P., and Savanurmath, C. (1994). Bacteriophages from Bombyx mori. Arch. Virol. 137, 185-190.

Bailey, T. L., Boden, M., Buske, F. A., Frith, M., Grant, C. E., Clementi, L., et al. (2009). MEME SUITE: tools for motif discovery and searching. Nucleic Acids Res. 37, W202-W208. doi: 10.1093/nar/gkp335

Barry, M., van Buuren, N., Burles, K., Mottet, K., Wang, Q., and Teale, A. (2010). Poxvirus exploitation of the ubiquitin-proteasome system. Viruses 2, 2356-2380. doi: 10.3390/v2102356

Bell, K. S., Sebaihia, M., Pritchard, L., Holden, M. T. G., Hyman, L. J., Holeva, M. C., et al. (2004). Genome sequence of the enterobacterial phytopathogen Erwinia carotovora subsp. atroseptica and characterization of virulence factors. Proc. Natl. Acad. Sci. U.S.A. 101, 11105-11110. doi: 10.1073/pnas.0402424101

Besemer, J., Lomsadze, A., and Borodovsky, M. (2001). GeneMarkS: a self-training method for prediction of gene starts in microbial genomes. Implications for finding sequence motifs in regulatory regions. Nucleic Acids Res. 29, 2607-2618.

Brewer, T. E., Stroupe, M. E., and Jones, K. M. (2014). The genome, proteome and phylogenetic analysis of Sinorhizobium meliloti phage $\Phi \mathrm{M} 12$, the founder of a new group of T4-superfamily phages. Virology 450-451, 84-97. doi: 10.1016/j.virol.2013.11.027

Briers, Y., Schmelcher, M., Loessner, M. J., Hendrix, J., Engelborghs, Y., Volckaert, G., et al. (2009). The high-affinity peptidoglycan binding domain of Pseudomonas phage endolysin KZ144. Biochem. Biophys. Res. Commun. 383, 187-191. doi: 10.1016/j.bbrc.2009.03.161

Briers, Y., Volckaert, G., Cornelissen, A., Lagaert, S., Michiels, C. W., Hertveldt, K., et al. (2007). Muralytic activity and modular structure of the endolysins of Pseudomonas aeruginosa bacteriophages $\varphi \mathrm{KZ}$ and EL. Mol. Microbiol. 65, 1334-1344. doi: 10.1111/j.1365-2958.2007.05870.x

Buttimer, C., O'Sullivan, L., Elbreki, M., Neve, H., McAuliffe, O., Ross, R. P., et al. (2016). Genome sequence of jumbo phage vB_AbaM_ME3 of Acinetobacter baumanni. Genome Announc. 4, e00431-e00416. doi: 10.1128/ genomeA.00431-16

Casjens, S. R., and Gilcrease, E. B. (2009). Determining DNA packaging strategy by analysis of the termini of the chromosomes in tailed-bacteriophage virions. Methods Mol. Biol. 502, 91-111. doi: 10.1007/978-1-60327-565-1_7

\section{FUNDING}

Funding was provided by Cork Institute of Technology as a $\mathrm{PhD}$ fellowship to CB.

\section{ACKNOWLEDGMENTS}

The authors thank Frank Seufert for technical assistance with phage preparation and Angela Back for her contribution to the preparation of the TEM images. This work was financed by Cork Institute of Technology project reference 2012BIOL The work in Rob Lavigne's laboratory was supported by the Geconcerteerde Onderzoeks Actie grant "Phage Biosystems" from KU Leuven.

\section{SUPPLEMENTARY MATERIAL}

The Supplementary Material for this article can be found online at: http://journal.frontiersin.org/article/10.3389/fmicb. 2017.00044/full\#supplementary-material

Comeau, A. M., and Krisch, H. M. (2008). The capsid of the T4 phage superfamily: the evolution, diversity, and structure of some of the most prevalent proteins in the biosphere. Mol. Biol. Evol. 25, 1321-1332. doi: 10.1093/molbev/msn080

Darrasse, A., Priou, S., Kotoujansky, A., and Bertheau, Y. (1994). PCR and restriction fragment length polymorphism of a pel gene as a tool to identify Erwinia carotovora in relation to potato diseases. Appl. Environ. Microbiol. 60, 1437-1443.

De Boer, S. H., and Ward, L. J. (1995). PCR detection of Erwinia carotovora subsp atroseptica associated with potato tissue. Phytopathology 85, 854-858. doi: 10.1094/Phyto-85-854

Delcher, A. L., Harmon, D., Kasif, S., White, O., and Salzberg, S. L. (1999). Improved microbial gene identification with GLIMMER. Nucleic Acids Res. 27, 4636-4641.

Drulis-Kawa, Z., Olszak, T., Danis, K., Majkowska-Skrobek, G., and Ackermann, H. W. (2014). A giant Pseudomonas phage from Poland. Arch. Virol. 159, 567-572. doi: 10.1007/s00705-013-1844-y

Dwivedi, B., Xue, B., Lundin, D., Edwards, R. A., and Breitbart, M. (2013). A bioinformatic analysis of ribonucleotide reductase genes in phage genomes and metagenomes. BMC Evol. Biol. 13:33. doi: 10.1186/1471-2148-13-33

Edgell, D. R., Gibb, E. A., and Belfort, M. (2010). Mobile DNA elements in T4 and related phages. Virol. J. 7:290. doi: 10.1186/1743-422X-7-290

Estrem, S. T., Gaal, T., Ross, W., and Gourse, R. L. (1998). Identification of an UP element consensus sequence for bacterial promoters. Proc. Natl. Acad. Sci. U.S.A. 95, 9761-9766.

Finn, R. D., Coggill, P., Eberhardt, R. Y., Eddy, S. R., Mistry, J., Mitchell, A. L., et al. (2015). The Pfam protein families database: towards a more sustainable future. Nucleic Acids Res. 44, D279-D285. doi: 10.1093/nar/gkv1344

Fouts, D. E., Klumpp, J., Bishop-Lilly, K. A., Rajavel, M., Willner, K. M., Butani, A., et al. (2013). Whole genome sequencing and comparative genomic analyses of two Vibrio cholerae O139 Bengal-specific Podoviruses to other N4-like phages reveal extensive genetic diversity. Virol. J. 10:165. doi: 10.1186/1743-422X-10-165

Fraser, J. S., Yu, Z., Maxwell, K. L., and Davidson, A. R. (2006). Ig-like domains on bacteriophages: a tale of promiscuity and deceit. J. Mol. Biol. 359, 496-507. doi: 10.1016/j.jmb.2006.03.043

Geiduschek, E. P., and Kassavetis, G. A. (2010). Transcription of the T4 late genes. Virol. J. 7:288. doi: 10.1186/1743-422X-7-288

Hatfull, G. F. (2008). Bacteriophage genomics. Curr. Opin. Microbiol. 11, 447-453. doi: $10.1016 /$ j.mib.2008.09.004

Hélias, V., Hamon, P., Huchet, E., Wolf, J. V. D., and Andrivon, D. (2012). Two new effective semiselective crystal violet pectate media for 
isolation of Pectobacterium and Dickeya. Plant Pathol. 61, 339-345. doi: 10.1111/j.1365-3059.2011.02508.x

Hendrix, R. W. (2002). Bacteriophages: evolution of the majority. Theor. Popul. Biol. 61, 471-480. doi: 10.1006/tpbi.2002.1590

Hendrix, R. W. (2009). Jumbo bacteriophages. Curr. Top. Microbiol. Immunol. 328, 229-240. doi: 10.1007/978-3-540-68618-7-7

Hertveldt, K., Lavigne, R., Pleteneva, E., Sernova, N., Kurochkina, L., Korchevskii, R., et al. (2005). Genome comparison of Pseudomonas aeruginosa large phages. J. Mol. Biol. 354, 536-545. doi: 10.1016/j.jmb.2005.08.075

Jones, D. T., Taylor, W. R., and Thornton, J. M. (1992). The rapid generation of mutation data matrices from protein sequences. Bioinformatics 8, 275-282. doi: 10.1093/bioinformatics/8.3.275

Käll, L., Krogh, A., and Sonnhammer, E. L. (2004). A combined transmembrane topology and signal peptide prediction method. J. Mol. Biol. 338, 1027-1036. doi: 10.1016/j.jmb.2004.03.016

Kanamaru, S., Leiman, P. G., Kostyuchenko, V. A., Chipman, P. R., Mesyanzhinov, V. V, Arisaka, F., et al. (2002). Structure of the cell-puncturing device of bacteriophage T4. Nature 415, 553-557. doi: 10.1038/415553a

Kang, H. W., Kwon, S. W., and Go, S. J. (2003). PCR-based specific and sensitive detection of Pectobacterium carotovorum ssp. carotovorum by primers generated from a URP-PCR fingerprinting-derived polymorphic band. Plant Pathol. 52, 127-133. doi: 10.1046/j.1365-3059.2003.00822.x

Keppel, F., Rychner, M., and Georgopoulos, C. (2002). Bacteriophage-encoded cochaperonins can substitute for Escherichia coli's essential GroES protein. EMBO Rep. 3, 893-898. doi: 10.1093/embo-reports/kvf176

Kim, M. S., Hong, S. S., Park, K., and Myung, H. (2013). Genomic analysis of bacteriophage PBECO4 infecting Escherichia coli O157:H7. Arch. Virol. 158, 2399-2403. doi: 10.1007/s00705-013-1718-3

Kumar, S., Stecher, G., and Tamura, K. (2016). MEGA7: molecular evolutionary genetics analysis version 7.0 for bigger datasets. Mol. Biol. Evol. 33, 1870-1874. doi: 10.1093/molbev/msw054

Laslett, D., and Canback, B. (2004). ARAGORN, a program to detect tRNA genes and tmRNA genes in nucleotide sequences. Nucleic Acids Res. 32, 11-16. doi: 10.1093/nar/gkh152

Li, S., Fan, H., An, X., Fan, H., Jiang, H., Chen, Y., et al. (2014). Scrutinizing virus genome termini by high-throughput sequencing. PLOS ONE 9:e85806. doi: 10.1371/journal.pone.0085806

Lingohr, E., Frost, S., and Johnson, R. P. (2009). Determination of bacteriophage genome size by pulsed-field gel electrophoresis. Methods Mol. Biol. 502, 19-25. doi: 10.1007/978-1-60327-565-1_3

Lowe, T. M., and Eddy, S. R. (1997). tRNAscan-SE: a program for improved detection of transfer RNA genes in genomic sequence. Nucleic Acids Res. 25, 955-964.

Mazzocco, A., Waddell, T. E., Lingohr, E., and Johnson, R. P. (2009). Enumeration of bacteriophages using the small drop plaque assay system. Methods Mol. Biol. 501, 81-85. doi: 10.1007/978-1-60327-164-6_9

Mesyanzhinov, V. V, Robben, J., Grymonprez, B., Kostyuchenko, V. A., Bourkaltseva, M. V, Sykilinda, N. N., et al. (2002). The genome of bacteriophage $\varphi \mathrm{KZ}$ of Pseudomonas aeruginosa. J. Mol. Biol. 317, 1-19. doi: 10.1006/jmbi.2001.5396

Mitchell, A., Chang, H. Y., Daugherty, L., Fraser, M., Hunter, S., Lopez, R., et al. (2014). The InterPro protein families database: the classification resource after 15 years. Nucleic Acids Res. 43, D213-D221. doi: 10.1093/nar/gku1243

Naville, M., Ghuillot-Gaudeffroy, A., Marchais, A., and Gautheret, D. (2011). ARNold: a web tool for the prediction of Rho-independent transcription terminators. RNA Biol. 8, 11-13.

Nelson, S. W., Zhuang, Z., Spiering, M. M., and Benkovic, S. J. (2009). “T4 phage replisome," in Viral Genome Replication. eds K. D. Raney, M. Gotte, and C. E. Cameron (Boston, MA: Springer), 337-364.

Nikolaichik, Y., Gorshkov, V., Gogolev, Y., Valentovich, L., and Evtushenkov, A. (2014). Genome sequence of Pectobacterium atrosepticum strain 21A. Genome Announc. 2:e00935-14. doi: 10.1128/genomeA.00935-14

Park, T. H., Choi, B. S., Choi, A. Y., Choi, I. Y., Heu, S., and Park, B. S. (2012). Genome sequence of Pectobacterium carotovorum subsp. carotovorum strain PCC21, a pathogen causing soft rot in Chinese cabbage. J. Bacteriol. 194, 6345-6346. doi: 10.1128/JB.01583-12
Petrov, V. M., Ratnayaka, S., Nolan, J. M., Miller, E. S., and Karam, J. D. (2010). Genomes of the T4-related bacteriophages as windows on microbial genome evolution. Virol. J. 7:292. doi: 10.1186/1743-422X-7-292

Pickard, D. J. (2009). Preparation of bacteriophage lysates and pure DNA. Methods Mol. Biol. 502, 3-9. doi: 10.1007/978-1-60327-565-1_1

Rahman, O., Cummings, S. P., Harrington, D. J., and Sutcliffe, I. C. (2008). Methods for the bioinformatic identification of bacterial lipoproteins encoded in the genomes of Gram-positive bacteria. World J. Microbiol. Biotechnol. 24, 2377-2382. doi: 10.1007/s11274-008-9795-2

Redzuan, R. A., Abu Bakar, N., Rozano, L., Badrun, R., Mat Amin, N., and Mohd Raih, M. F. (2014). Draft genome sequence of Erwinia mallotivora BTMARDI, causative agent of Papaya Dieback Disease. Genome Announc. 2, e00375-e00314. doi: 10.1128/genomeA.00375-14

Rocha, E. P., and Danchin, A. (2002). Base composition bias might result from competition for metabolic resources. Trends Genet. 18, 291-294. doi: 10.1016/S0168-9525(02)02690-2

Sambrook, J., and Russell, D. W. (2001a). "Preparing stocks of bacteriophage lamda by plate lysis and elution," in Molecular Cloning: A Laboratory Manual, Vol. 1 (New York, NY: Cold Spring Harbor Laboratory Press), 2.34.

Sambrook, J., and Russell, D. W. (2001b). "Plating bacteriophage lamda," in Molecular Cloning: A Laboratory Manual, 3rd Edn., Vol. 1 (New York, NY: Cold Spring Harbor Laboratory Press), 2.25.

Sambrook, J., and Russell, D. W. (2001c). "Purification of bacteriophage lamda particles by isopycnic centrifugation through $\mathrm{CsCl}$ gradients," in Molecular Cloning: A Laboratory Manual, Vol. 1 (New York, NY: Cold Spring Harbor Laboratory Press), 2.47.

Samson, J. E., Magadán, A. H., Sabri, M., and Moineau, S. (2013). Revenge of the phages: defeating bacterial defences. Nat. Rev. Microbiol. 11, 675-687. doi: $10.1038 /$ nrmicro3096

Schweiger, M., Hennig, K., Lerner, F., Niere, M., Hirsch-Kauffmann, M., Specht, T., et al. (2001). Characterization of recombinant human nicotinamide mononucleotide adenylyl transferase (NMNAT), a nuclear enzyme essential for NAD synthesis. FEBS Lett. 492, 95-100. doi: 10.1016/S0014-5793(01) 02180-9

Sengupta, R., and Holmgren, A. (2014). Thioredoxin and glutaredoxin-mediated redox regulation of ribonucleotide reductase. World J. Biol. Chem. 5, 68-74. doi: 10.4331/wjbc.v5.i1.68

Serwer, P., Hayes, S. J., Thomas, J. A., and Hardies, S. C. (2007). Propagating the missing bacteriophages: a large bacteriophage in a new class. Virol. J. 4:21. doi: 10.1186/1743-422X-4-21

Šimolūnas, E., Kaliniene, L., Truncaite, L., Zajanckauskaite, A., Staniulis, J., Kaupinis, A., et al. (2013). Klebsiella phage vB_KleM-RaK2 - a giant singleton virus of the family Myoviridae. PLoS ONE 8:e60717. doi: 10.1371/journal.pone.0060717

Skurnik, M., Hyytiäinen, H. J., Happonen, L. J., Kiljunen, S., Datta, N., Mattinen, L., et al. (2012). Characterization of the genome, proteome, and structure of yersiniophage $\varphi$ R1-37. J. Virol. 86, 12625-12642. doi: 10.1128/JVI.01783-12

Söding, J., Biegert, A., and Lupas, A. N. (2005). The HHpred interactive server for protein homology detection and structure prediction. Nucleic Acids Res. 33, W244-W248. doi: 10.1093/nar/gki408

Sullivan, M. B., Coleman, M. L., Quinlivan, V., Rosenkrantz, J. E., Defrancesco, A. S., Tan, G., et al. (2008). Portal protein diversity and phage ecology. Environ. Microbiol. 10, 2810-2823. doi: 10.1111/j.1462-2920.2008.01702.x

Sullivan, M. J., Petty, N. K., and Beatson, S. A. (2011). Easyfig: a genome comparison visualizer. Bioinformatics 27, 1009-1010. doi: 10.1093/ bioinformatics/btr039

Szewczyk, B., Bienkowska-Szewczyk, K., and Kozloff, L. M. (1986). Identification of T4 gene 25 product, a component of the tail baseplate, as a $15 \mathrm{~K}$ lysozyme. Mol. Gen. Genet. 202, 363-367.

Tori, K., and Perler, F. B. (2011). Expanding the definition of class 3 inteins and their proposed phage origin. J. Bacteriol. 193, 2035-2041. doi: 10.1128/JB. 01407-10

Tsones, J. (2014). Use of Bacteriophages as Antimicrobials against Avian Pathogenic Escherichia coli Infections in Poultry: from Isolation to Therapeutic. KU Leuven and Vrije Universiteit Brussel. 
Turner, D., Reynolds, D., Seto, D., and Mahadevan, P. (2013). CoreGenes3.5: a webserver for the determination of core genes from sets of viral and small bacterial genomes. BMC Res. Notes 6:140. doi: 10.1186/1756-0500-6-140

Van den Bossche, A., Ceyssens, P. J., De Smet, J., Hendrix, H., Bellon, H., Leimer, N., et al. (2014). Systematic identification of hypothetical bacteriophage proteins targeting key protein complexes of Pseudomonas aeruginosa. J. Proteome Res. 13, 4446-4456. doi: 10.1021/pr500796n

Van Twest, R., and Kropinski, A. M. (2009). Bacteriophage enrichment from water and soil. Methods Mol. Biol. 501, 15-21. doi: 10.1007/978-1-60327-164-6_2

Walldén, K., Rinaldo-Matthis, A., Ruzzenente, B., Rampazzo, C., Bianchi, V., and Nordlund, P. (2007). Crystal structures of human and murine deoxyribonucleotidases: insights into recognition of substrates and nucleotide analogues. Biochemistry 46, 13809-13818. doi: 10.1021/bi7014794

Wang, L. K., Schwer, B., and Shuman, S. (2006). Structure-guided mutational analysis of T4 RNA ligase 1. RNA 12, 2126-2134. doi: 10.1261/rna.271706

Whitman, W. B., Coleman, D. C., and Wiebe, W. J. (1998). Perspective prokaryotes: the unseen majority. Proc. Natl. Acad. Sci. U.S.A. 95, 6578-6583.

Xu, M., Struck, D. K., Deaton, J., Wang, I. N., and Young, R. (2004). A signalarrest-release sequence mediates export and control of the phage P1 endolysin. Proc. Natl. Acad. Sci. U.S.A. 101, 6415-6420. doi: 10.1073/pnas.0400957101

Yuan, Y., and Gao, M. (2016). Proteomic analysis of a novel Bacillus jumbo phage revealing glycoside Hydrolase as structural component. Front. Microbiol. 7:745. doi: $10.3389 /$ fmicb. 2016.00745
Zhong, Y., Chen, F., Wilhelm, S. W., Poorvin, L., and Hodson, R. E. (2002) Phylogenetic diversity of marine cyanophage isolates and natural virus communities as revealed by sequences of viral capsid assembly protein gene g20. Appl. Environ. Microbiol. 68, 1576-1584. doi: 10.1128/AEM. 68.4.1576-1584.2002

Zhu, N., Olivera, B. M., and Roth, J. R. (1991). Activity of the nicotinamide mononucleotide transport system is regulated in Salmonella typhimurium. J. Bacteriol. 173, 1311-1320.

Zuker, M. (2003). Mfold web server for nucleic acid folding and hybridization prediction. Nucleic Acids Res. 31, 3406-3415.

Conflict of Interest Statement: The authors declare that the research was conducted in the absence of any commercial or financial relationships that could be construed as a potential conflict of interest.

Copyright (c) 2017 Buttimer, Hendrix, Oliveira, Casey, Neve, McAuliffe, Ross, Hill, Noben, O'Mahony, Lavigne and Coffey. This is an open-access article distributed under the terms of the Creative Commons Attribution License (CC BY). The use, distribution or reproduction in other forums is permitted, provided the original author(s) or licensor are credited and that the original publication in this journal is cited, in accordance with accepted academic practice. No use, distribution or reproduction is permitted which does not comply with these terms. 